\title{
Article \\ Understanding Haze: Modeling Size-Resolved Mineral Aerosol from Satellite Remote Sensing
}

\author{
Nivedita Sanwlani ${ }^{1, *(D)}$ and Reshmi Das ${ }^{2,3}$ (D) \\ 1 Satellite Remote Sensing Centre, Nanyang Technological University, Singapore 639798, Singapore \\ 2 School of Environmental Studies, Jadavpur University, Kolkata 700032, India; \\ reshmidas.sest@jadavpuruniversity.in \\ 3 Earth Observatory of Singapore, Nanyang Technological University, Singapore 639798, Singapore \\ * Correspondence: nsanwlani@ntu.edu.sg
}

Citation: Sanwlani, N.; Das, R. Understanding Haze: Modeling Size-Resolved Mineral Aerosol from Satellite Remote Sensing. Remote Sens. 2022, 14, 761. https://doi.org/ $10.3390 /$ rs14030761

Academic Editors: Maria João Costa, Oleg Dubovik, Patricia K. Quinn and Jean-Christophe Raut

Received: 24 December 2021

Accepted: 3 February 2022

Published: 7 February 2022

Publisher's Note: MDPI stays neutral with regard to jurisdictional claims in published maps and institutional affiliations.

Copyright: (C) 2022 by the authors. Licensee MDPI, Basel, Switzerland. This article is an open access article distributed under the terms and conditions of the Creative Commons Attribution (CC BY) license (https:// creativecommons.org/licenses/by/ $4.0 /)$.

\begin{abstract}
Mineral dust aerosols are composed of a complex mixture of silicates, carbonates, oxides, and sulfates. The minerals' chemical composition and size distribution are vital parameters to evaluate dust environmental impacts. However, the quantification of minerals remains a challenge due to the sparse in situ measurements of dust samples. Here we derive the size-resolved mineralogical composition of airborne dust aerosols from MODIS (Terra and Aqua) satellite-acquired optical measurements and compare it with chemically analyzed elemental ( $\mathrm{Al}, \mathrm{Fe}, \mathrm{Ca}, \mathrm{Mg}$ ) concentrations of aerosols for $\mathrm{PM}_{2.5}$ and $\mathrm{PM}_{10}$ from Chonburi, Chiang Rai, and Bangkok in Thailand, and from Singapore. MODIS-derived mineral retrievals exhibited high correlations with elemental concentrations with $\mathrm{R}^{2} \geq 0.84$ for $\mathrm{PM}_{2.5}$ and $\geq 0.96$ for $\mathrm{PM}_{10}$. High mineral dust activity was detected in the vicinity of biomass-burning areas with gypsum and calcite exhibiting tracer characteristics of combustion. The spatiotemporal pattern of the MODIS-derived minerals matched with Ozone Monitoring Instrument (OMI)-derived dust, sulfates, and carbonaceous aerosols, indicating the model's consistency. Variation in aerosol loading by $\pm 90 \%$ led to deviation in the mineral concentration by $<10 \%$. An uncertainty of $6.4 \%$ between AERONET-measured and MODIS-derived AOD corresponds to $a< \pm 2 \%$ uncertainty in MODIS-derived mineral concentration, demonstrating the robustness of the model.
\end{abstract}

Keywords: mineral dust aerosol; aerosol size distribution; MODIS; OMI; AERONET; Southeast Asia; biomass burning

\section{Introduction}

Mineral dust produced by wind erosion is the ubiquitous and dominant component of the atmospheric particulate matter (PM) that plays a pivotal role in Earth's climate system. Mineral aerosols serve as cloud condensation and ice nuclei [1], thus stimulating precipitation and impacting the hydrological cycle. Nutrients such as iron in the aerosol stimulate biological productivity by fertilizing ecosystems upon deposition, thus influencing the global carbon cycle [2,3]. Mineral dust is highly sensitive to variations in the climate and has demonstrated potential feedback capabilities on the climate system and contrariwise [4]. These atmospheric particulates degrade the air quality and adversely affect human health by causing acute physical and psychological distress when transported over densely populated areas. Choking air pollution can irritate the respiratory tract and eyes, exacerbate cardiovascular diseases, and cause severe long-term health damage [5-7]. In particular, the finest, insoluble particles could be the most detrimental to health $[8,9]$. The spatiotemporal distribution of the mineralogical aerosols and their environmental impacts are evaluated based on two key parameters: relative abundance and composition.

There has been increasing interest in designing reliable and robust numerical aerosol models to simulate size-resolved mineral composition during dust emission and subsequent chemical transformation during atmospheric transport [10-14]. Aerosol particles' 
diverse chemical, microphysical, and optical properties can be determined using in situ sampling devices [15]. Characterization of dust particles can be achieved through measurements on composition, surface area, shape, size distribution, and mixing rate [16]. The distribution of mineral dust in the atmosphere is regulated by dust-emission sources, which are exceptionally responsive to atmospheric and surface conditions. These surface conditions are dynamic, with constantly evolving land-use patterns and climate change. Hence, simulating the complicated processes involved during emission and transport and predicting the size-resolved aerosol mineral composition is challenging [14].

Most aerosol retrievals are based on models that consider a mixture of homogeneous spherical aerosol particles of different sizes with a chemical composition represented by the complex refractive index, which satisfactorily reproduces the observed aerosol properties [17]. Additionally, [18] demonstrated that the particles' effect of non-sphericity and non-homogeneity on the single-scattering phase function is small ( $20 \% \pm 15 \%)$. The entire matrix of wavelength-dependent aerosol single-scattering properties is pre-computed and listed in look-up tables in more recent climate models to circumvent the highly timeconsuming Mie calculations for each aerosol type. These look-up tables are implemented for quick and accurate simulations of the aerosol properties as a function of the particle size at specific intervals $[17,19,20]$.

We used Mie's theory (assuming homogenous spherical particles) for pre-computation of wavelength-dependent single-scattering properties for nine dust minerals at different grain sizes (generating 91 dust models in total) and listed them in a look-up table. The physical principle of mineral detection relies on the spectral distribution pattern of the dust particle absorption and scattering corresponding to each mineral constituent across the optical and infrared wavelengths. Therefore, the mineral identification scheme employs a mathematical optimization approach between the satellite-acquired optical properties and the microphysical properties tabulated in our designed mineral suite. Here, we present an inversion model for the size-resolved mineralogical composition of aerosols from the matrix of spectral optical properties varying as a function of the particle size. The model is demonstrated using MODIS-Aqua and Terra multispectral optical measurements over Southeast Asia.

Validation of the MODIS-generated mineral composition derived from the model is essential to ensure the best estimates for further utilization in global climatological models. However, the mineralogical composition of aerosols is rarely quantified in in situ collected dust samples. Moreover, optical imaging satellite observations rely on cloud-free conditions, and the heavy cloud cover across Southeast Asia interferes with satellite retrievals. Due to the lack of direct in situ mineral composition data, three different validation approaches were attempted to corroborate our MODIS-generated mineral concentrations. (a) The quantitative performance of the model was evaluated by comparing the satellite-derived mineral retrievals with chemically analyzed elemental ( $\mathrm{Al}, \mathrm{Fe}, \mathrm{Ca}, \mathrm{Mg}$ ) concentrations of aerosols for $\mathrm{PM}_{2.5}$ and $\mathrm{PM}_{10}$ from four terrestrial locations in Southeast Asia. (b) The spatiotemporal pattern of MODIS-derived mineral composition was qualitatively compared with an Ozone Monitoring Instrument (OMI)-derived ultraviolet (UV)-based Aerosol Index (AI) and aerosol types. (c) The uncertainties associated with the derivation of mineral concentrations were computed by comparing satellite-derived and ground-based aerosol robotic network (AERONET)-derived mineral concentrations using the same model. In addition, a sensitivity analysis of MODIS-derived mineral concentrations was carried out to determine the robustness of the model and dispersion of the mineral concentrations with respect to variation in AOD. The mineralogical analysis will contribute towards designing dust hazard mitigation techniques, assessing dust surface radiative forcing, and understanding the role of aerosol mineralogy in climate and environment modeling. 


\section{Materials and Methods}

\subsection{Remote Sensing Input}

We downloaded the MODIS Collection 6.1, Level 2 product (MOD04_L2) at a spatial resolution of $10 \mathrm{~km}$ from https:/ / ladsweb.modaps.eosdis.nasa.gov / (accessed on 1 June 2021), and extracted the following aerosol properties for land and ocean:

(a) AOD centered at 550, 860, $2100 \mathrm{~nm}$ over the sea.

(b) AOD centered at 412, 470, and $650 \mathrm{~nm}$ over the land.

AOD is an operational product computed using two retrieval procedures: (a) Dark Target (DT) algorithm over visually dark regions [21] and (b) Deep Blue algorithm over bright-desert regions [22]. The updated collection 6.1 has successfully reduced the high biases observed over urban pixels compared to ground-based AERONET AODs with a high correlation $[23,24]$ which resulted in an increase $(>20 \%)$ in the number of retrievals falling within the expected error \% range at the global scale. This gives us the confidence that MODIS AOD retrievals can be considered an accurate and reliable "standard" for identifying mineralogical compositions.

Aura Ozone Monitoring Instrument Level 2 near UV Aerosol operational data products was downloaded from NASA's https:/ / disc.gsfc.nasa.gov/datasets /OMAERUV_00 3/ (accessed on 1 June 2021). The two UV-based products, UV aerosol index (UVAI), and the classification of aerosol types, are based on decoupling the spectral radiances from molecular scattering and aerosol effects at two wavelengths in the near-UV region [25]. Negative UVAI values (<-0.2) represent non-absorbing aerosol particles. Near-zero values of \pm 0.2 UVAI correspond to either the negligible aerosol condition in the atmosphere or the presence of coarse-mode non-absorbing particles and clouds.

\subsection{Dust Mineral Suit Input}

Individual aerosol particles are typically mixtures of liquid droplets and solid dry components that have absorption and scattering (non-absorbing) properties. Absorbing particles represent carbonaceous particles and dust minerals, while the scattering components represent sulfate, nitrate, sea salt, etc. $[19,26,27]$. Dust consists of various minerals, chiefly silicates, carbonates, iron oxides, and sulfates, varying with the emission source. Hence, we designed a mineral suite based on globally abundant uniform size fractions of mineral dust content in natural aerosols [28] so that the satellite identification procedure replicates the size and mineralogy compared to eolian soil. With spherical diameter $<2 \mu \mathrm{m}$, phyllosilicates (illite, kaolinite, and montmorillonite) comprise the clay-sized silicate fraction. Tectosilicates (feldspar, mica, and quartz) covered the coarser silt- (2-50 $\mu \mathrm{m}$ diameter) and sand- (>50 $\mu \mathrm{m}$ diameter) sized counterparts. Silicates have strong mineral-specific infrared absorption band centers, which aids in their identification from remote sensing [29,30]. Iron-rich hematite clay $(<2 \mu \mathrm{m})$ has intense UV and visible absorption, which is further enhanced when aggregated with silicate clay minerals [30,31]. In contrast, clay-silt-sized carbonates (calcite) and clay-silt-sand-sized sulfates have strong infrared absorption but no UV absorption. Overall, we have incorporated nine minerals with a diverse set (clay, silt, sand) of particle sizes (Table A1), yielding a total of 91 mineral models in our suite to invert aerosol mineralogy at a location. The real and imaginary components of the complex refractive index for the nine dust minerals in the window (0-2200 nm) are exhibited in Figure A1. Although other minerals occur in much smaller quantities in the atmosphere, we have included the nine major minerals (silicates and non-silicates) that play potential roles in climate and biogeochemical processes $[10,26]$. The differences in the microphysical properties between minerals form the basis for this paper's dust detection technique.

\subsection{Elemental Metal Measurements for Validation}

Concentrations of four elements ( $\mathrm{Al}, \mathrm{Fe}, \mathrm{Ca}, \mathrm{Mg})$ in different size fractions $\left(\mathrm{PM}_{2.5}\right.$, $\left.\mathrm{PM}_{10}\right)$ were measured in the aerosol from Chonburi $\left(\mathrm{PM}_{2.5}\right.$ monthly sampling for JanuaryDecember 2018), Chiang Rai ( $\mathrm{PM}_{2.5}$ weekly sampling for January-April 2019), and Bangkok $\left(\mathrm{PM}_{2.5}\right.$ monthly sampling for February 2018-December 2019) in Thailand [32,33] and 
Singapore ( $\mathrm{PM}_{10}$ during 2013 and 2016-2017). Aerosol samples were collected on $47 \mathrm{~mm}$ PTFE filters using a portable low-volume particulate sampler pump (Deployable Particulate Sampler from Leland Legacy) with a flow rate of $10 \mathrm{~L} / \mathrm{min}$. Samples were collected for $24 \mathrm{hrs}$ from $6 \mathrm{AM}$, once every week. The metals in the aerosols were dissolved in a 50\% 3:1 ( $/ \mathrm{v}$ ) HNO3:HF dissolution mixture to ensure the complete dissolution of silicate minerals. The extracted solution was measured using an inductively coupled plasma mass spectrometer (ICP-MS, Thermo Element 2) at the Earth Observatory of Singapore. The chemical extraction procedure and ICP-MS analytical details are published in [32]. The major elements in minerals modeled in [32] are oxygen $(\mathrm{O})$, silicon ( $\mathrm{Si})$, aluminum ( $\mathrm{Al}$ ), iron $(\mathrm{Fe})$, calcium $(\mathrm{Ca})$, potassium $(\mathrm{K})$, sodium $(\mathrm{Na})$, magnesium $(\mathrm{Mg})$, and sulfur $(\mathrm{S})$. In this study, only $\mathrm{Al}, \mathrm{Fe}, \mathrm{Ca}$, and $\mathrm{Mg}$ were used for comparison with the minerals.

Table A2 gives the empirical formulae of the most commonly occurring minerals. The major Ca-bearing minerals are calcite ( $40 \% \mathrm{Ca}$ ) and gypsum $(23 \% \mathrm{Ca})$. The major Fe-bearing mineral is hematite $(70 \% \mathrm{Fe})$. Figure A2 shows a pie chart of the relative contribution of each mineral towards total $\mathrm{Al}, \mathrm{Fe}, \mathrm{Ca}$, and $\mathrm{Mg}$ measured in the dust aerosol. For example, the measured Fe concentrations are plotted against $83 \%$ hematite $+15 \%$ mica $+2 \%$ illite MODIS-derived mineral concentrations. As quartz consists of $\mathrm{Si}$ and $\mathrm{O}$, none of which were measured in situ, it was excluded from the mineral-metal comparison. The crustal enrichment factor $(\mathrm{EF})$ is often used to quantify anthropogenic inputs over the natural background.

$$
\mathrm{EF}=\frac{(\text { metal } / \mathrm{ref} \cdot \text { metal })_{\text {aerosol }}}{(\text { metal } / \text { ref } \cdot \text { metal })_{\text {crust }}}
$$

The measured element ratios are generally compared with the average upper continental crustal (UCC) composition [34]. Typically, crustal elements such as Fe, $\mathrm{Al}$, Ti are chosen as the reference element; we chose $\mathrm{Al}$ as the reference element in this study. The sources of the elements in the atmosphere can be a combination of natural background and anthropogenic inputs. Elements with a natural origin should have EF $~ 1$. However, to account for the local variability of upper continental crust composition, which forms the immediate precursor of the aerosol metals, $\mathrm{EF} \leq 10$ is considered to have a natural origin. Thus, while selecting in situ chemical measurement data, only metals with $\mathrm{EF} \leq 10$ were considered to eliminate the influence of anthropogenic sources of these elements.

\subsection{Ground-Based AERONET-AOD Data for Validation}

AERONET ground-based measurements are a widely accepted standard benchmark for assessing the satellite-estimated aerosol products. The observations are available for a broad range of visible to near-infrared bands $(0.34-1.02 \mu \mathrm{m})$ and have been reported to have a low bias of 0.01-0.02 [35]. Cloud-screened and quality-assured L2.0 AERONET AOD (accessed at http:/ / aeronet.gsfc.nasa.gov, accessed on 1 June 2021) were downloaded for Chiang Rai, Bangkok, and Singapore corresponding to the in situ elemental measurement dates. The AOD at these stations is recorded every $15 \mathrm{~min}$ for seven spectral bands (340, $380,440,500,670,870$, and $1020 \mathrm{~nm}$ ) and does not provide AOD measurements at 550 and $860 \mathrm{~nm}$. Therefore, to match MODIS-derived AOD at $550 \mathrm{~nm}$ and AE at 550/860 nm, AERONET AOD values at 550 and $860 \mathrm{~nm}$ were interpolated using the AERONET angstrom exponent at $500-870 \mathrm{~nm}$. Notably, the location of the AERONET stations and the sampling for in situ chemical analysis does not match but are closer to each other. Hence, in our case, we assume that the AERONET stations are capturing a similar air parcel as sampled for in situ chemical analysis. Additionally, Chonburi does not have an AERONET station; hence the MODIS-AERONET comparison was restricted to three sites.

\subsection{Modeling Size-Resolved Mineralogical Composition}

A simple way of representing the AOD spectrum and the size of the aerosol particles is by using the Ångström power law [36]:

$$
\tau(\lambda)=\beta \lambda^{-\alpha}
$$


where $\tau$ is AOD, $\alpha$ is the Ångström Exponent (AE), $\beta$ is the turbidity, and $\lambda$ is the wavelength. The Ångström Exponent characterizes the spectral variation of AOD and is represented by the Volz function as the slope of the logarithm of the aerosol optical depth (AOD) versus the logarithm of the wavelength:

$$
\alpha=-\frac{\ln \frac{\tau\left(\lambda_{1}\right)}{\tau\left(\lambda_{2}\right)}}{\ln \frac{\lambda_{2}}{\lambda_{1}}}
$$

The band-averaged AODs were first converted to mono-spectral AODs using the corresponding spectral response functions. The mono-spectral AODs were utilized to compute AE at 550-860 nm and 860-2100 nm for the ocean and at 412-470 and 470-650 nm for land using the Volz method, which was then employed to finally yield mono-spectral AOD $(550 \mathrm{~nm})$ and AE $(550 / 860 \mathrm{~nm})$ for both land and ocean. These two parameters eventually furnished a combined land-ocean reconstructed spectral AOD profile from $380-2200 \mathrm{~nm}$ at a $15 \mathrm{~nm}$ interval using the Volz method (Equation (3), using the respective $\mathrm{AE}$ for the spectral range), which was used to infer aerosol mineralogy. However, we acknowledge that the reconstructed spectral AOD profile could be further enhanced by employing hyperspectral measurements of AOD. Assuming that aerosols are homogenous spheres of particle radius $r, \tau$ is expressed as a complex function of the columnar aerosol size distribution and chemical composition, described by the Fredholm integral equations of the first kind [37]:

$$
\tau\left(\lambda_{\mathrm{i}}\right)=\frac{\pi}{4} \int_{0}^{\infty} \mathrm{Q}_{\text {ext }}\left(\mathrm{\eta}\left(\lambda_{\mathrm{i}}\right), \mathrm{r}\right) \cdot \mathrm{n}(\mathrm{r}) \cdot \mathrm{r}^{2} \cdot \mathrm{dr}
$$

where $\mathrm{n}(\mathrm{r})$ is the mineral size distribution in a vertical column of air (i.e., the number of particles per unit area per unit radius level), $\eta$ is the complex refractive index of the aerosol particles, and $Q_{\text {ext }}(r, \lambda, \eta)$ is the extinction efficiency factor from Mie theory. The approximate discretization of the integral Equation (4) into a system (sum) of linear equations for a wavelength $\lambda_{\mathrm{i}}$ is represented by:

$$
\begin{gathered}
a\left(\lambda_{i}, r_{j}\right)=\frac{\pi}{4} Q_{\text {ext }}\left(\eta\left(\lambda_{i}\right), r_{j}\right) \cdot r_{j}{ }^{2} \\
\left(\lambda_{i}\right)=\sum_{j=1}^{N=91} a_{i j} \cdot n\left(r_{j}\right)+C_{i}\left(\lambda_{i}\right)
\end{gathered}
$$

Each aerosol type (minerals in our case) is associated with a unique spectral distribution of microphysical properties, as represented in Equation (5). The AOD spectrum (Equation (4) is thus decoupled into these defined 91 spectral models (of different mineral types and particle sizes) from our mineral suite in Equation (6). The wavelength-dependent optical properties such as the extinction efficiency $\left(\mathrm{Q}_{\text {ext }}\right)$, single-scattering albedo, and asymmetry factor of the particle of each mineral type (from 91 models) are pre-computed and tabulated in LUT (Equation (4) by supplying the size parameter $(2 \pi r / \lambda)$ and complex refractive index as the input parameters through the Lorenz-Mie theory for homogeneous spheres [38-40]. The real and imaginary components of the complex refractive index for common dust minerals in the window $(0-2200 \mathrm{~nm})$ are exhibited in Appendix A. This allows us to compare the spectral shape of each mineral dust model (91 mineral models) in terms of the best fit with the observed AOD spectrum. The unique solution for the number concentration $\left(n\left(r_{j}\right)\right)$ associated with each mineral model (out of 91 models) in Equation (6) is then computed by non-negative least-squares (NNLS) regularization [41]. The assumption of any power-law or log-normal distribution function for particle size $n(r)$ in the proposed model is avoided, and the exact number of particles for each group of particle sizes is calculated by finding the non-negative solution of the equations in the study.

In brief, the mineral concentration is derived by matching the spectral shape of AOD with 91 models from the mineral suite. It should be noted that the contribution from other aerosol types is not assumed to be insignificant. The concentration of any 'dust' 
and 'non-dust' aerosol types that are not included in the model library is accounted for through the non-negative residual term $C_{i}\left(\lambda_{i}\right)$. The residual term $C_{i}\left(\lambda_{i}\right)$ represents the contribution from all other aerosol types such as sea salt, black carbon, organic aerosols, etc., which are currently not explicitly included in the model due to the lack of in situ measurements for validation. The advantageous feature of the model is that it can be expanded for other aerosol types and sizes as needed, provided that suitable validation data become available. Because our spectral library or mineral suite includes nine types of dust minerals of clay-silt-sand-size, which are commonly observed suspended in air and in particular during a dust event, the model can thus simulate the range of mineral optical signatures for any region.

\subsection{Limitations of Mineral Aerosol Model}

The model presumes that a suitable atmospheric correction has been applied to the input satellite data to invert the correct AOD spectral profile. An improper atmospheric correction applied to imagery could introduce a significant source of error. Additionally, the satellite AOD retrieval algorithms for land and ocean differ, and therefore some biases in the mineral estimates between land and ocean regions are expected. Fine-sized particles have a stronger optical signature than coarse particles. Hence, the observed mineralogical signals over the marine environment are more distinctive than land areas. Optical imaging satellite observations rely on cloud-free conditions, and heavy cloud cover interferes with satellite retrievals. Misclassification of thick aerosol plumes as water clouds can confuse the physical interpretation and disrupt quantitative analyses. Consequently, the assimilation of remotely sensed aerosol and mineral products was diligently planned, and quantitative estimates were carefully interpreted so that the relative patterns over land and ocean regions were accurate.

Dust minerals have indicative absorption bands in the spectral range of 400-2500 nm. Both multispectral and hyperspectral remote sensing can effectively capture spectral characteristics. Geologists have been using this technique for mineral resource exploration, identification, mapping minerals, and soil type discrimination [42,43]. We acknowledge that hyperspectral remote sensing certainly has the advantage of capturing the subtle spectral variations between the minerals. However, the daily spatial coverage of such hyperspectral sensors to monitor aerosol dynamics is limited. Data integration (multi- and hyperspectral) can enhance our capabilities of complete assessment. The spectral library used for mineral inversion does not explicitly include other aerosol types other than dust minerals. However, the spectral library could easily be expanded to include subgroups of non-dust if necessary. Expanding the spectral library beyond dust minerals to carbonaceous particles will aid us in understanding smoke and dust interactions. Expanding the library further to hygroscopic sea salt will help us understand the role played by marine aerosols in aerosol-cloud interactions. There are still further improvements that could help us to expand our understanding of dust aerosol models globally.

\section{Results}

\subsection{Satellite-Derived Size-Resolved Mineral Aerosol Composition}

Two clear non-dusty and two dusty (total four) satellite imageries from the MODIS were selected to demonstrate the application of the model from the validation datasets (elemental concentrations of in situ collected aerosols) acquired over Southeast Asia (Figure 1a). The MODIS-derived spatial distributions of AOD (550 nm) and AE (550-860 nm) exhibit an extensive range of apparent aerosol loadings throughout the region (Figure 1b,c). A high concentration of continental dust is observed over terrestrial regions, with its widespread influence extending to the coastal areas. Coastal environments receive a mixture of marinegenerated sea-spray aerosols and land-advected continental flux. The spatial gradients of AE (550-860 nm) in Figure 1c display contrasting differences between the clean marine $(\mathrm{AE}<1)$ and terrestrial air masses $(\mathrm{AE}>1)$. A significant increase in aerosol loading with 
AOD $(500 \mathrm{~nm})>0.5$ and AE $(550-860 \mathrm{~nm})$ slightly $>1$ is observed around Thailand and nearby regions during the dusty days.
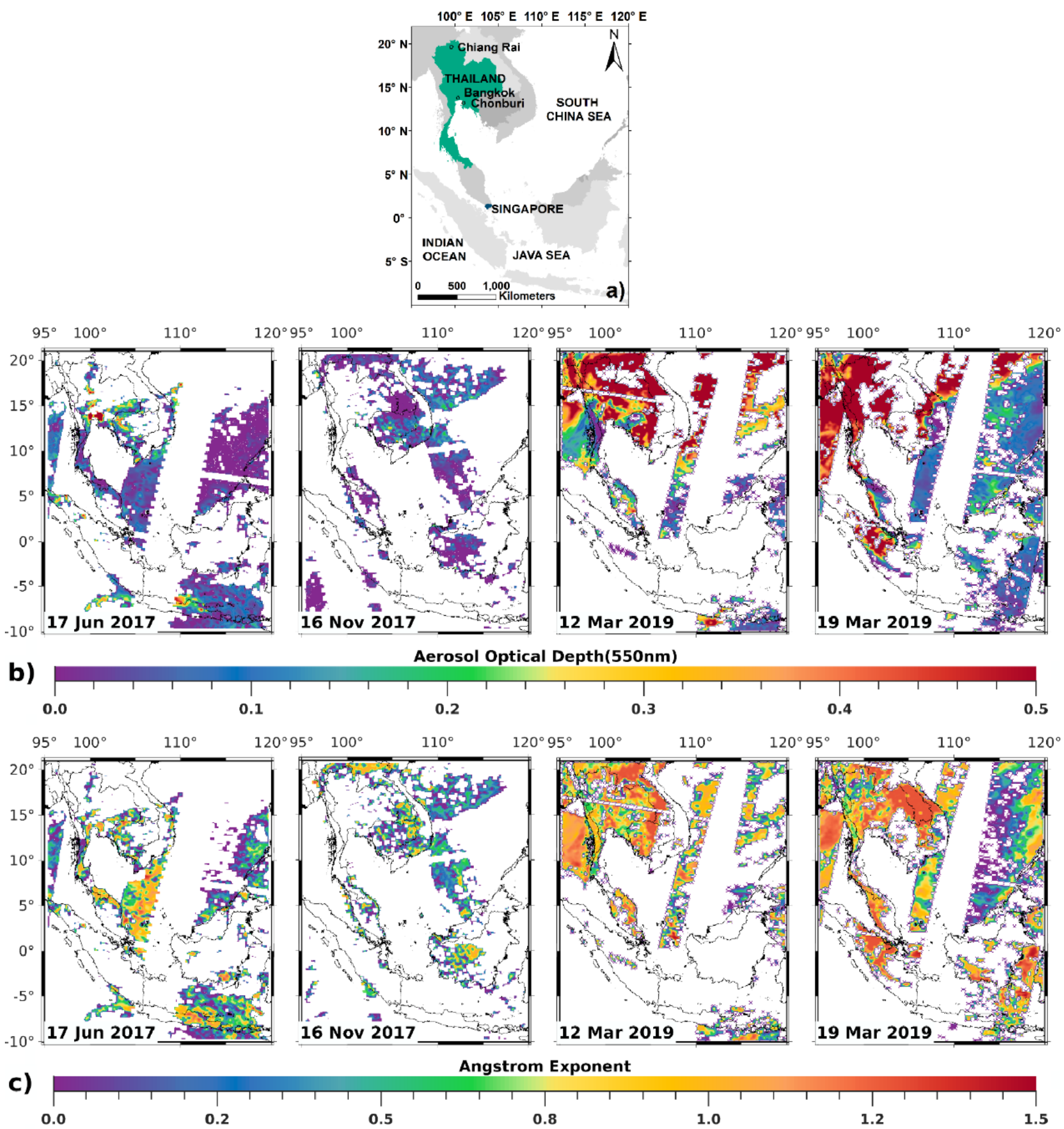

Figure 1. (a) Map of the Southeast Asia study domain showing validation locations Chonburi, Chiang Rai, and Bangkok located in Thailand and Singapore; (b) spatial distribution of MODIS-derived aerosol optical depth (AOD) at $550 \mathrm{~nm}$; (c) spatial distribution of MODIS-derived Angstrom exponent (AE) for 550-860 nm encompassing Southeast Asian region corresponding to two non-dusty and two dusty days from the validation dataset.

MODIS-derived spatial distribution of nine minerals (calcite, feldspar, gypsum, hematite, illite, kaolinite, mica, montmorillonite, and quartz) captured the mineral dust composition of aerosols throughout the Southeast Asian region (Figures 2-4) and demonstrated that 
the model performed well. It should be noted that the spatial distribution of minerals is dependent on their estimated concentration. Hence, the data coverage of minerals will be different than that of $\mathrm{AOD}$, i.e., if a particular mineral concentration is estimated to be 0 , it is represented as a white color in the figures.
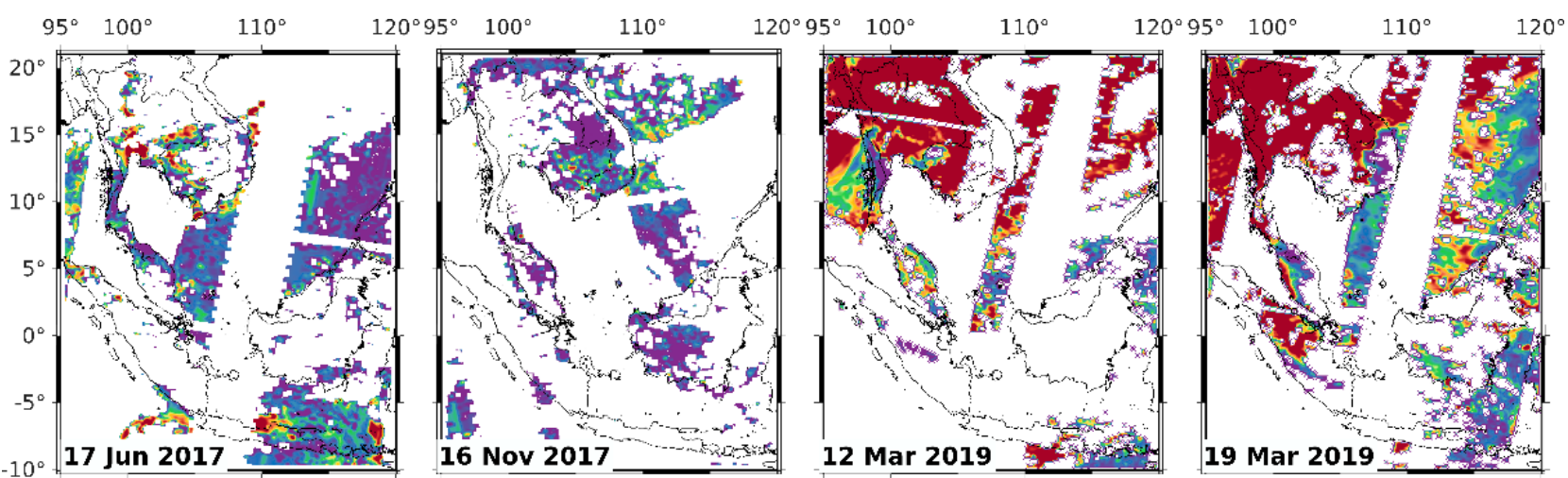

a)
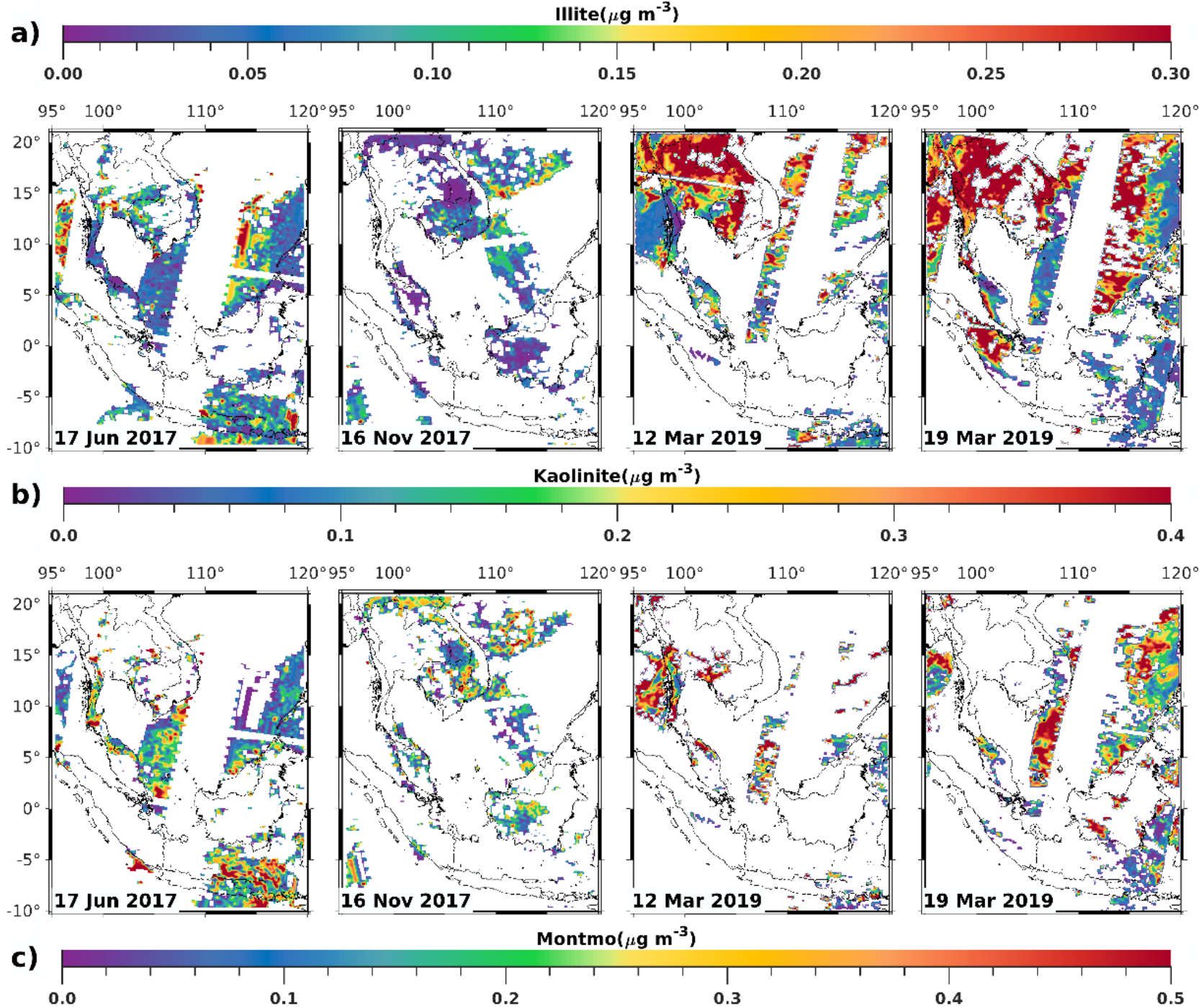

Figure 2. Spatial distribution of MODIS-derived phyllosilicates minerals (diameter $<2 \mu \mathrm{m}$ ) (a) illite; (b) kaolinite; (c) montmorillonite for Southeast Asian region corresponding to corresponding to two non-dusty and two dusty days from the validation dataset. 

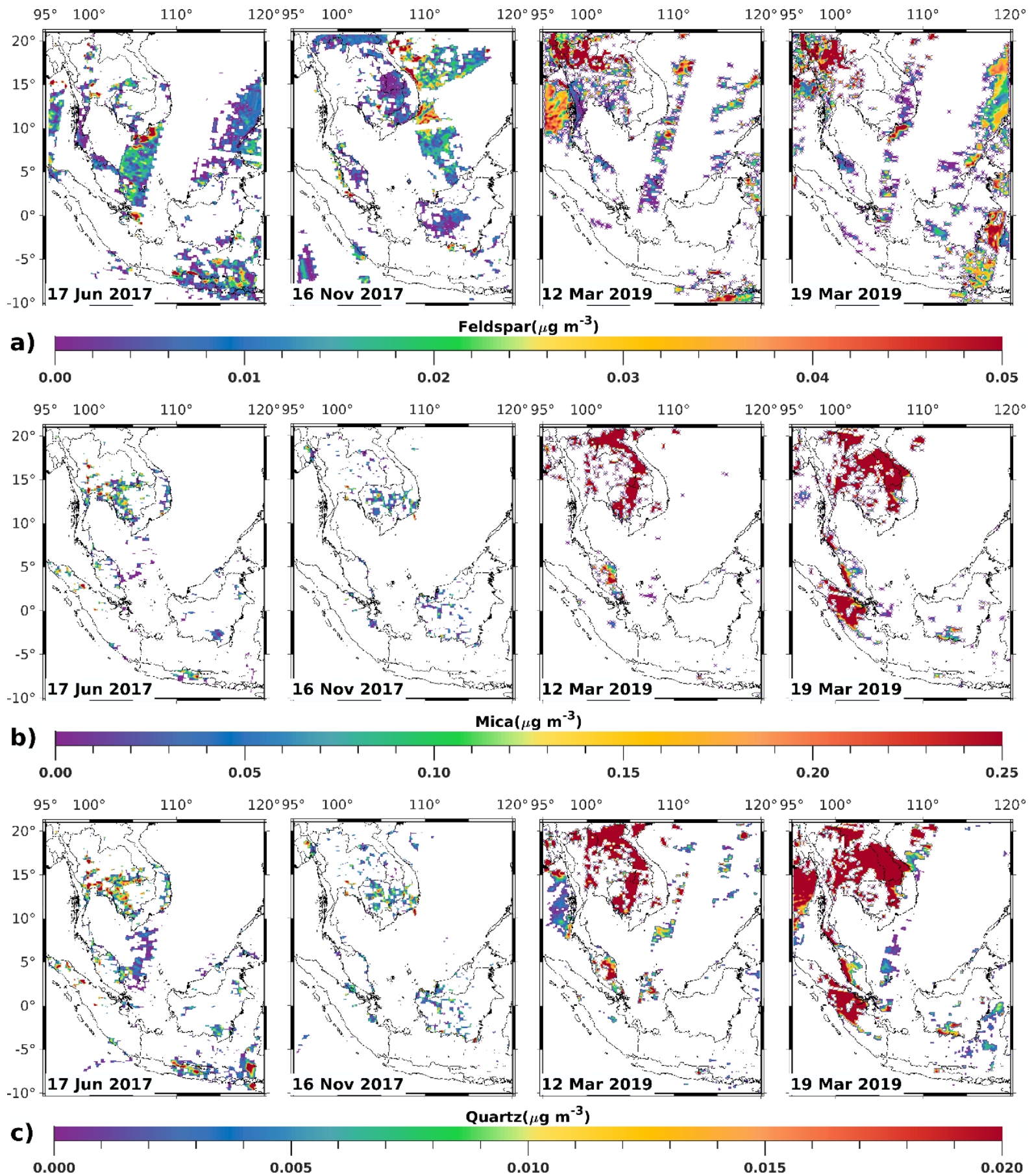

Figure 3. Spatial distribution of MODIS-derived tectosilicates minerals (diameter: 2-50 $\mu \mathrm{m}$ ) (a) feldspar; (b) mica; (c) quartz for Southeast Asian region corresponding to corresponding to two non-dusty and two dusty days from the validation dataset.

Copious amounts of phyllosilicates (illite, kaolinite, and montmorillonite) prevailing over the entire region (Figure 2) indicate that the dust is being enriched in clay-sized alumino-silicates and is also being advected to the marine atmosphere during a haze event. Similarly, traces of tectosilicates (feldspar, mica, and quartz) are observed (Figure 3) in small quantities, probably near the dust emission sources over the terrestrial region. Interestingly, calcium carbonate (calcite) was discerned in the MODIS-derived mineralogy over the terrestrial regions on dusty days (Figure 4a) near the dust emission sources. Besides phyllosilicates, a substantial contribution from hematite was observed in our 
MODIS-derived mineralogy (Figure $4 \mathrm{~b}$ ) over both land and oceanic regions. The presence of hematite shows that ferric oxide is abundant over the entire region that can easily be transported to marine areas, being fine-sized. Prominent traces of sulfates in the form of gypsum, detected on hazy days (Figure 4c), can be a significant portion of fine particulate matter $\left(\mathrm{PM}_{2.5}\right)$ that can induce a wide range of adverse health effects.
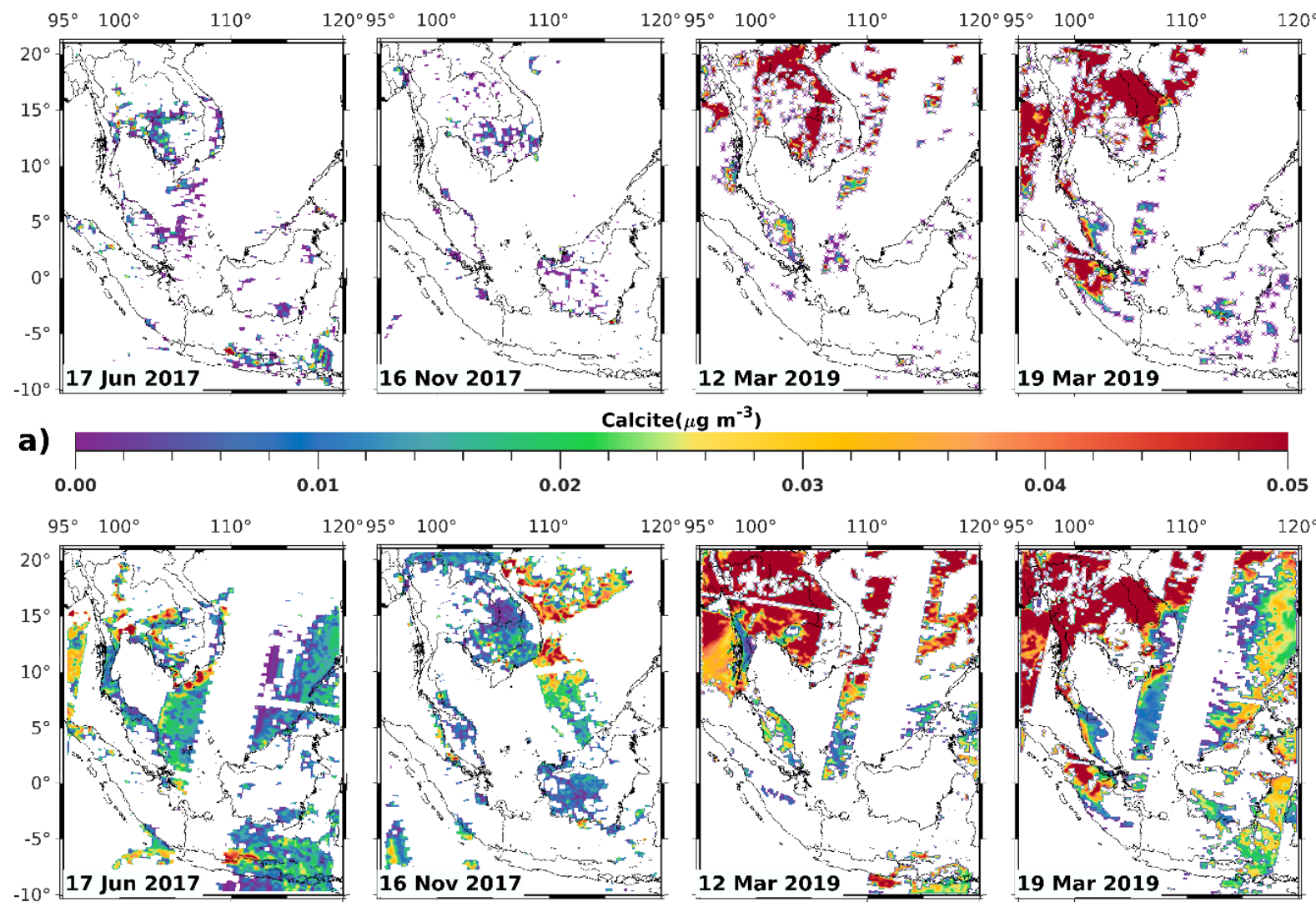

b)
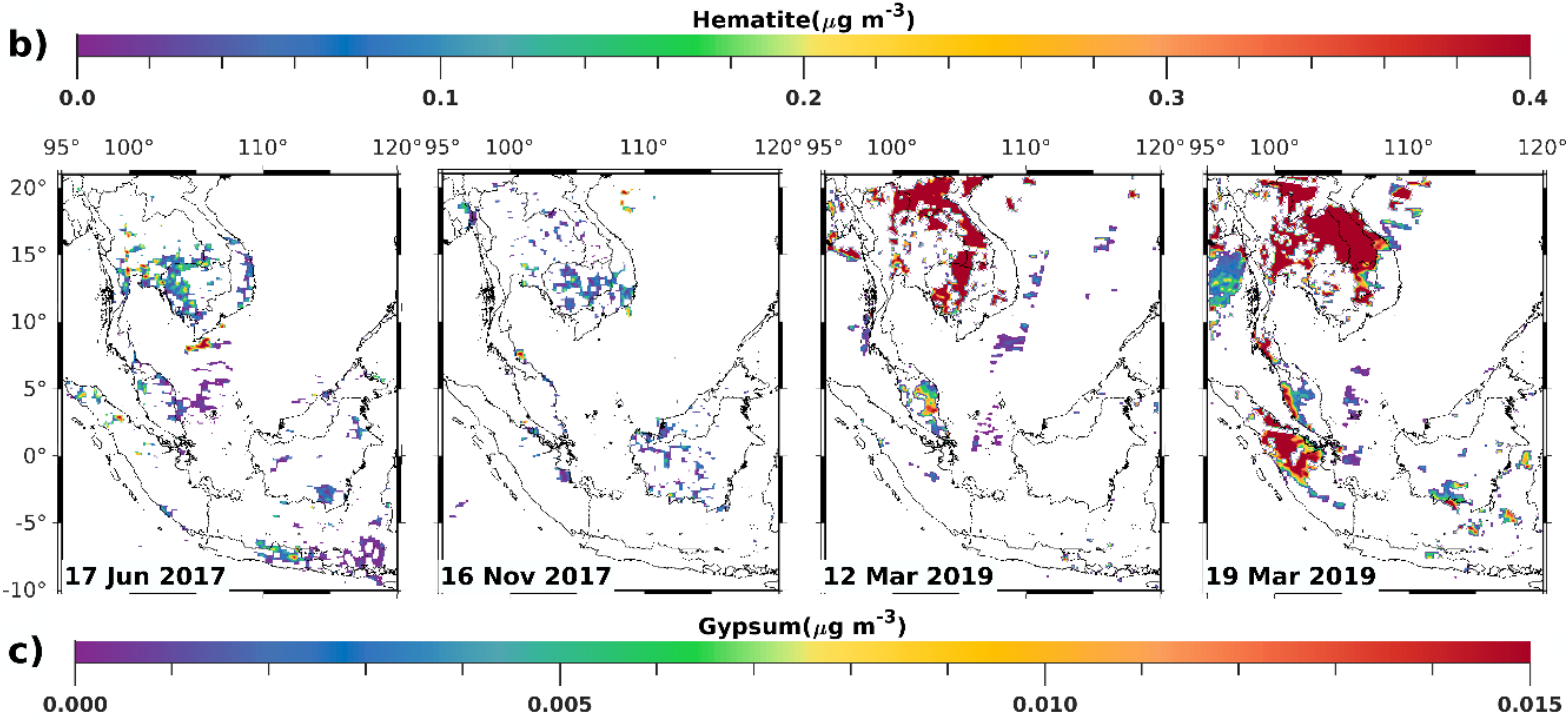

Figure 4. Spatial distribution of MODIS-derived carbonate, ferric-oxide, and sulfate minerals (a) calcite; (b) hematite; (c) gypsum for Southeast Asian region corresponding to two non-dusty and two dusty days from the validation dataset.

MODIS-derived spatial distribution of the percentage of clay ( $<2 \mu \mathrm{m}$ diameter) and silt (2-50 $\mu \mathrm{m}$ diameter) minerals are shown in Figure A3. In contrast, the sand particles (>50 $\mu \mathrm{m}$ diameter) were found to be absent for Southeast Asia. The small, submicron 
clay-sized aerosols observed in the particle size spectra (Figure 5) are pronounced $(>70 \%)$ over both terrestrial and marine areas, contributing significantly to the AOD. The mean size distribution of dust aerosols displays a bi-modal spread dominated by fine-sized clay particles ranging from $0.2-0.7 \mu \mathrm{m}$ with a secondary peak at $0.9-1.0 \mu \mathrm{m}$ on a clean, non-dusty day. An increase in the number concentrations by a factor of five was noted, along with two additional minor peaks with maxima at $>2 \mu \mathrm{m}$ for the wind-mobilized coarser silt particles on a hazy day.
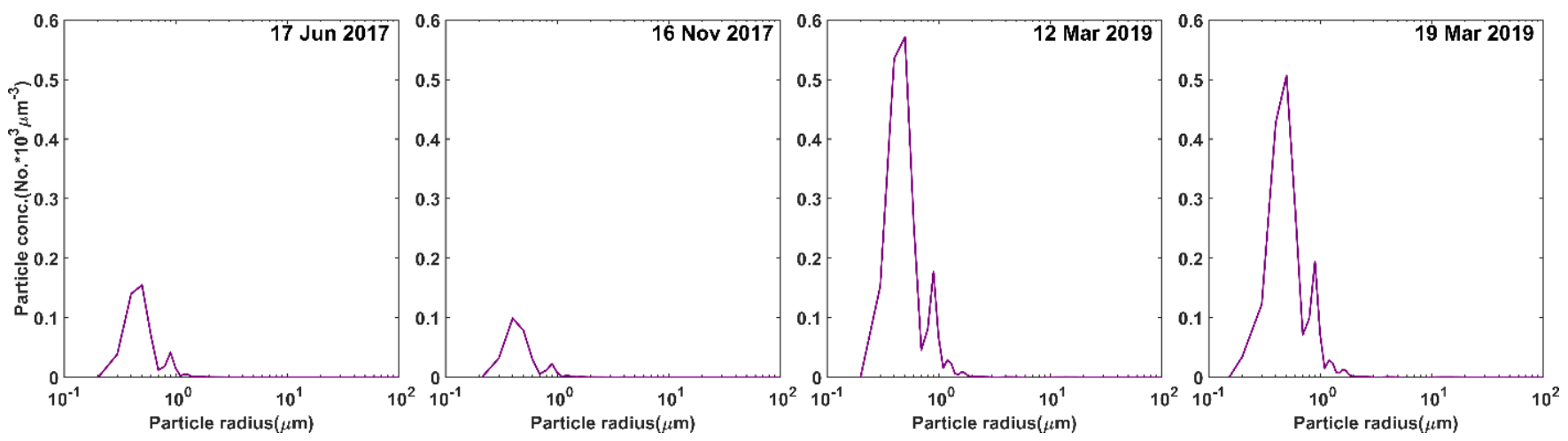

Figure 5. Mineral size distribution displaying MODIS-derived mean grain size for Southeast Asia region corresponding to two non-dusty and two dusty days from the validation dataset.

\subsection{Validation of the Size-Resolved Mineral Aerosol Model}

Southeast Asia experiences high levels of cloud cover throughout the year due to its geographical location. This severely limits the number of in situ satellite matchups. Hence, in total, we obtained 60 satellite matchups out of 150 in situ measurements covering four different terrestrial locations-Chonburi (20 out of 39), Chiang Rai (4 out of 10), Bangkok (20 out of 37), and Singapore (16 out of 64) - each with different atmospheric conditions and contaminants. The MODIS mineral retrievals exhibited good correlations with four chemically analyzed elemental ( $\mathrm{Al}, \mathrm{Ca}, \mathrm{Fe}$, and $\mathrm{Mg}$ ) concentrations of aerosols (Figure 6) from Chonburi $\left(\mathrm{PM}_{2.5}\right)$, Chiang Rai $\left(\mathrm{PM}_{2.5}\right)$, Bangkok $\left(\mathrm{PM}_{2.5}\right)$, and Singapore $\left(\mathrm{PM}_{10}\right)$. The strength of regression was described using the coefficient of determination $\left(\mathrm{R}^{2}\right)$. MODIS-derived mineralogy demonstrated an $\mathrm{R}^{2} \geq 0.84$ for $\mathrm{PM}_{2.5}$ elemental concentrations and $\geq 0.96$ for $\mathrm{PM}_{10}$. This indicates that $\geq 84$ and $\geq 96 \%$ variance in $\mathrm{PM}_{2.5}$ and $\mathrm{PM}_{10}$ minerals considered in this study is explained by the variance of its respective elemental concentrations (Figure 6). The correlation coefficient (r, Pearson) indicates the strength of a relationship. The Pearson coefficient $r \geq 0.95$ for $\mathrm{PM}_{2.5}$ and $\geq 0.99$ for $\mathrm{PM}_{10}$ signifies a strong relationship between the mineral and elemental concentrations. These correlations were statistically significant $(p<<0.005)$. However, bias or uncertainty associated with MODISderived minerals cannot be interpreted from mineral-metal correlations. Nevertheless, low values of the $y$-intercept suggest that the 1:1 line is passing from the origin 0:0 and the close distribution along the 1:1 line indicates a high correlation. 

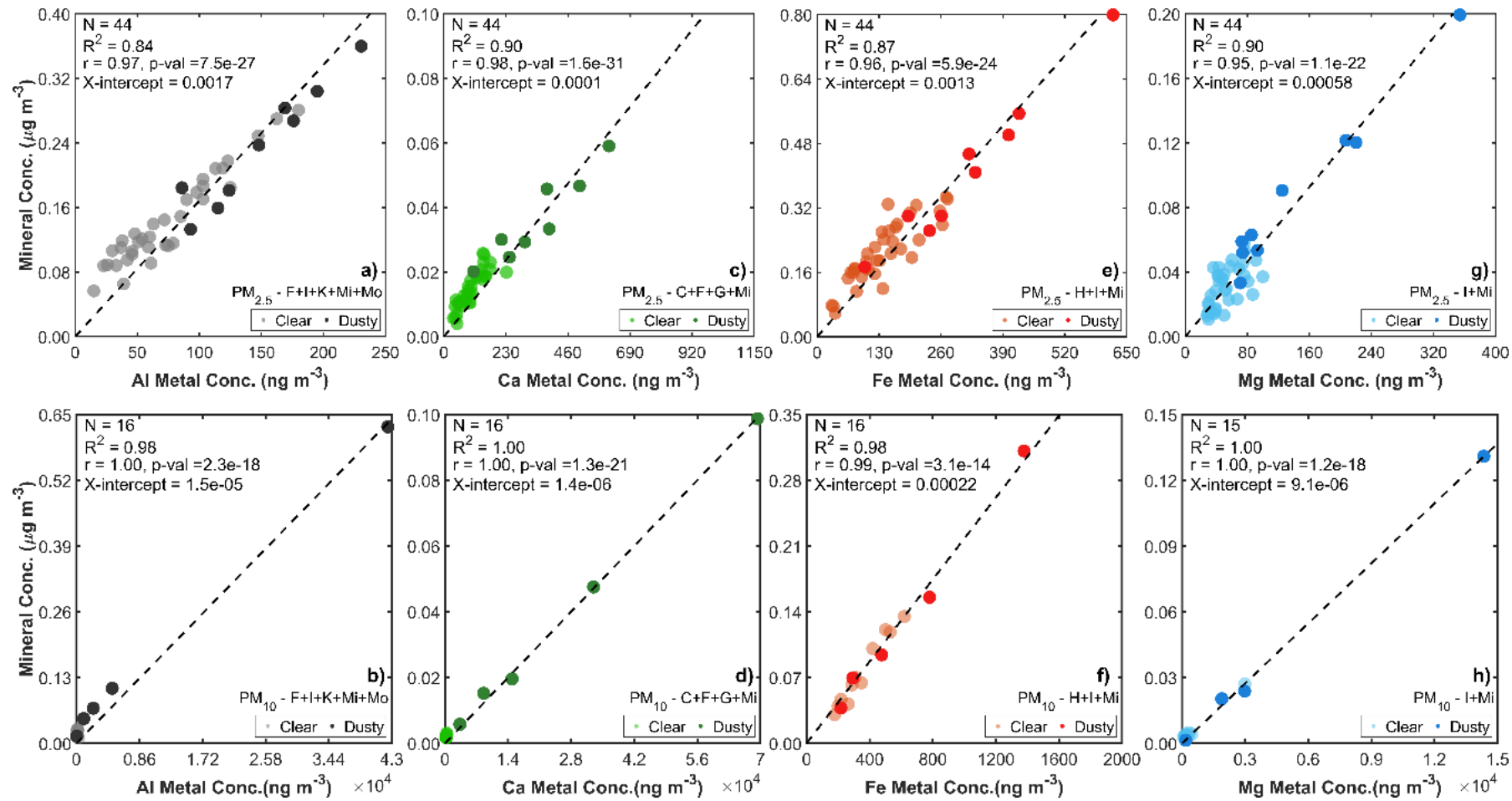

Figure 6. Comparison plots of MODIS-derived minerals (relative contribution, refer SI: Table A2 and Figure A2) with in situ measured and chemically analyzed elemental concentration of (a,b) Aluminum-Al; (c,d) Calcium-Ca; (e,f) Iron-Fe; (g,h) Magnesium-Mg. Panels (a,c,e,g) show the comparison of minerals with the elemental concentration of size fraction $\mathrm{PM}_{2.5}$ measured over Chonburi, Chiang Rai, and Bangkok, while panels $(\mathbf{b}, \mathbf{d}, \mathbf{f}, \mathbf{h})$ show the comparison of minerals with the elemental concentration of size fraction $\mathrm{PM}_{10}$ measured over Singapore. The light shade of the color shows clear non-dusty days, while the darker shades show the data corresponding to the dusty days.

The UVAI values and aerosol types classified by OMI aided us in validating aerosol types identified by our model. The appearance of higher quantities of smoke tracer minerals - calcite and gypsum (indicated by red color in Figure 4) — during a fire event in MODIS-derived mineralogy (Figure 3) is coherent (co-located) with the OMI detected smoke aerosols (gray color in Figure 7a). This reinforces that the model accurately captures the smoke-generated aerosols released during biomass burning. Higher quantities of tectosilicates-feldspar, mica, and quartz (indicated by red color in Figure 3) - further exemplify dust entrainment into convective fire plumes and matches with OMI detected dust aerosols. The OMI-classified dust aerosols (brown color in Figure 7a) are also spatially and temporally coherent with higher quantities of all the minerals. 


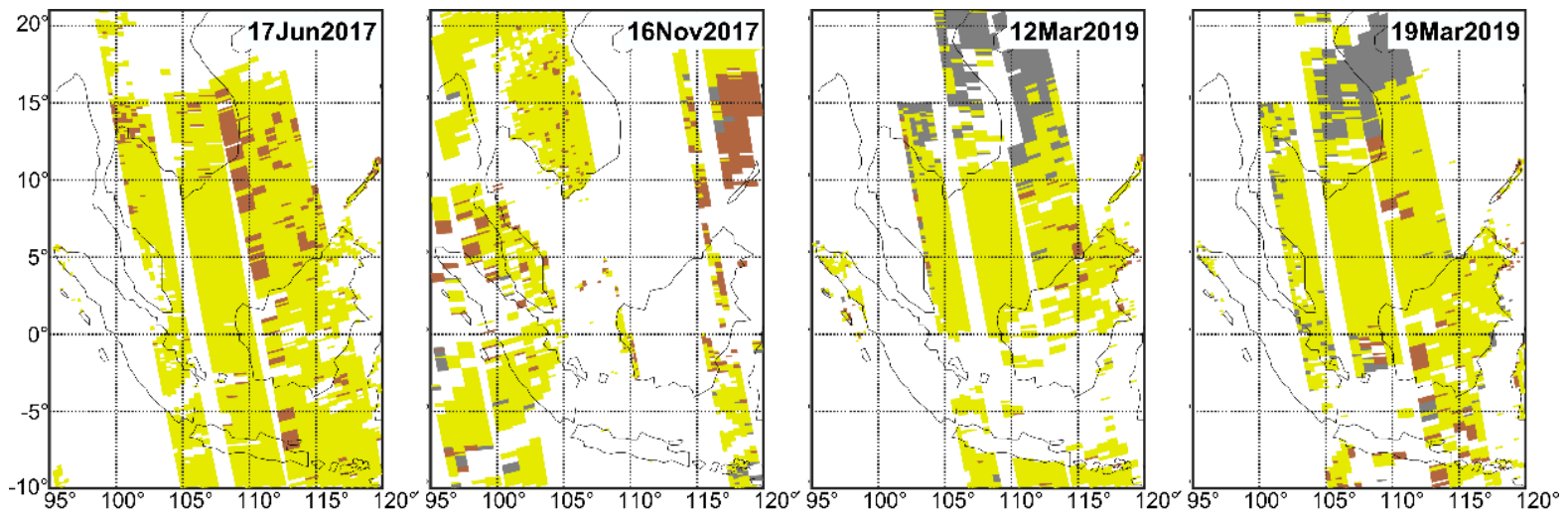

a)

Aerosol Type
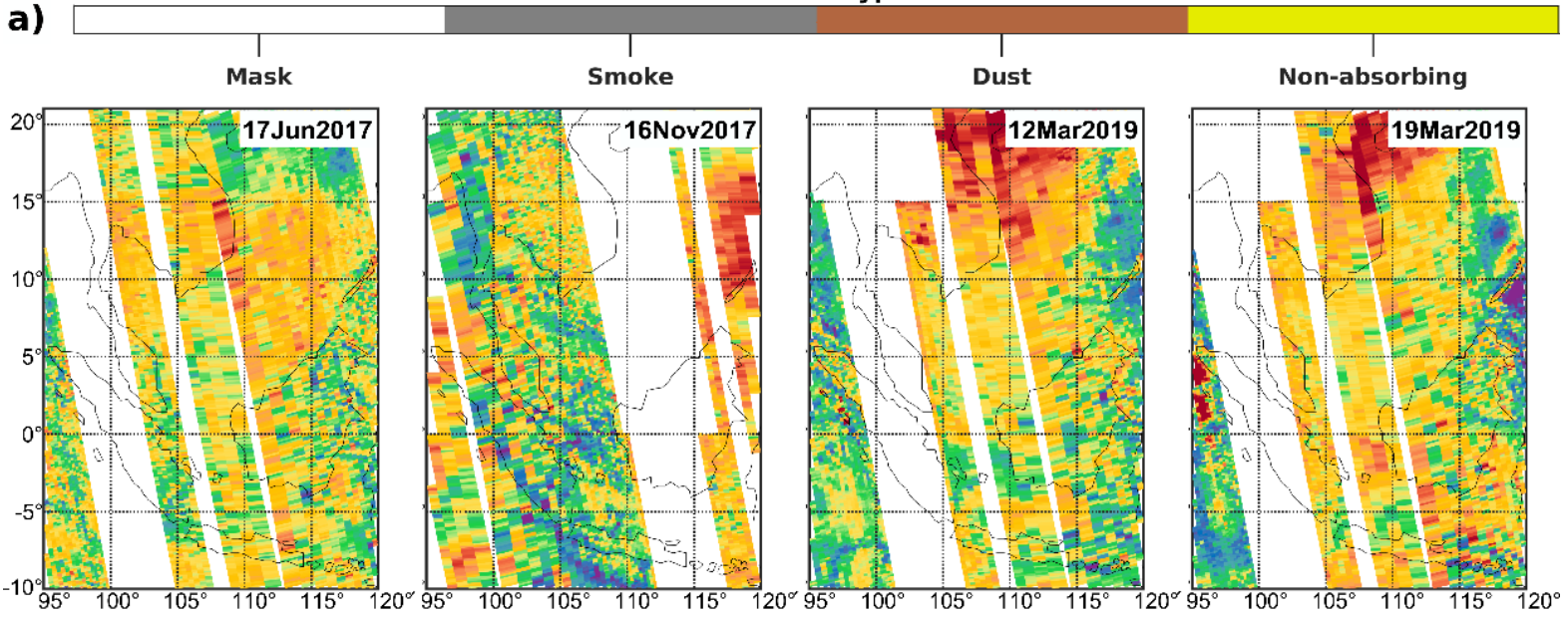

b)

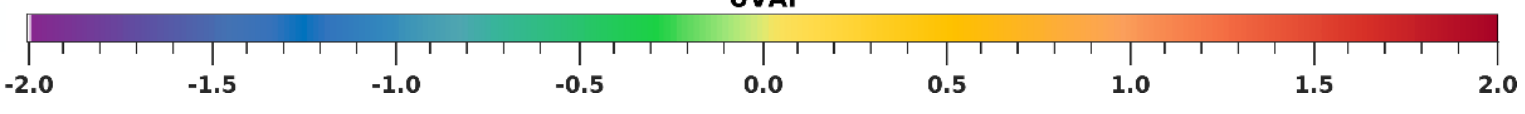

Figure 7. Spatial distribution of (a) aerosol type (b) UV aerosol index (AI) derived from Ozone Monitoring Instrument (OMI) sensor on Aura satellite differentiating between smoke, dust, and weak or non-absorbing aerosols corresponding to two non-dusty and two dusty days from the validation dataset.

AERONET-measured AOD and AE were used to derive the mineral concentrations using the proposed model. Hence, MODIS-derived mineral concentrations were compared with AERONET-derived mineral concentrations, and the performance of the proposed model was evaluated using root mean square error (RMSE) and mean absolute percentage error (MAPE). AERONET AOD sun-photometer installations are fewer in number and have limited spatial coverage. Hence, in total, we obtained 16 satellite cloud-screened and quality-assured L2.0 AERONET AOD matchups out of 80 in situ chemical measurements covering Chiang Rai, Bangkok, and Singapore.

On average, the percentage deviation between satellite-derived and AERONETmeasured AOD at $550 \mathrm{~nm}$ (Figure 8 ) ranged from -22 to $+10.5 \%$, with a mean absolute percentage error (MAPE) of $6.4 \%$. The AE tends to be overestimated in dusty regions for particles with effective radii between 0.26 and $2.8 \mu \mathrm{m}$ [44]. However, AE in our analysis varied from -5.3 to $+7.2 \%$ ( $\mathrm{MAPE}=2.4 \%$ ), retaining the shape of the AOD spectra so that the composition of the minerals derived from the model remains unaltered. The MODIS-retrieved mineral concentrations exhibited strong correlations with AERONETderived mineral concentrations (Figure 8), with the strength of regression $R^{2} \geq 0.95$ for all the minerals. Low values of RMSE $\leq 0.047 \mu \mathrm{g} \mathrm{m}^{-3}$ and MAPE $\leq 19 \%$ except for calcite $(\sim 149 \%)$ and feldspar $(\sim 32 \%)$ are indicative of a high correlation between AERONET and MODIS-derived minerals. 

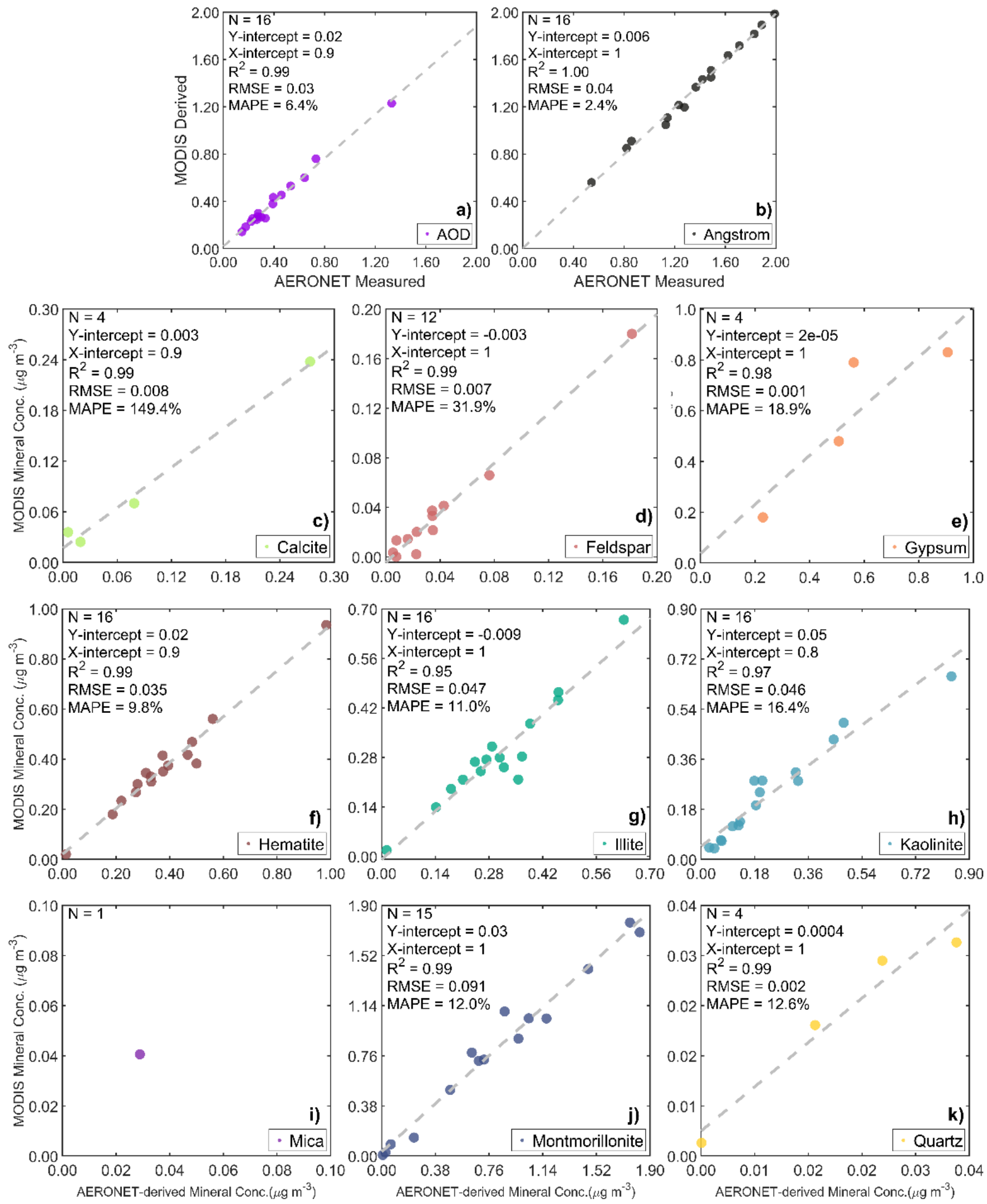

Figure 8. Comparison plots of MODIS satellite derived and AERONET (a) measured aerosol optical depth (AOD); (b) measured Angstrom exponent (AE) used to compute mineral concentrations for (c) calcite; (d) feldspar; (e) gypsum; (f) hematite; (g) illite; (h) kaolinite; (i) mica; (j) montmorillonite; (k) quartz.

A sensitivity assessment analysis was performed to investigate the response of the dust-mineral distribution with respect to the varying AOD values. Hence, input AOD was altered in steps of $\pm 10, \pm 30, \pm 50, \pm 70, \pm 90 \%$ to assess the corresponding sensitivity and variability in (a) the concentration of each mineral and (b) the particle size distribution. For 
a demonstration of spatial variability purposes, the average distribution of deviation in a mineral concentration corresponding to a $+50 \%$ rise in AOD is shown here (Figure 9). Regions with larger AOD values (Figure 1) typically demonstrated higher deviation in each mineral (Figure 9); however, the variation of AOD does not increase the mineral contribution linearly (Figure 10). The errors for the aerosol loading AOD $<0.25$ are observed to be smaller than $2 \%$; hence, the deviation in the mineral retrieval observed over the oceanic region is smaller than the terrestrial region. This implies that the deviation will be highest in the vicinity of the dust emission sources over terrestrial regions $(>2 \%)$. The most sensitive minerals noticed in this region are iron-rich hematite, illite, and kaolinite (Figures 9 and 10) over both land and ocean for all the categories of AOD deviation. A maximum deviation of $\sim 10 \%$ was noted corresponding to $+30 \%$ deviation in AOD and remained $<10 \%$ for the variation in the aerosol loading by $\pm 90 \%$. Deviation for the rest of the minerals is approximately half of the deviation of these three sensitive minerals for all the categories.

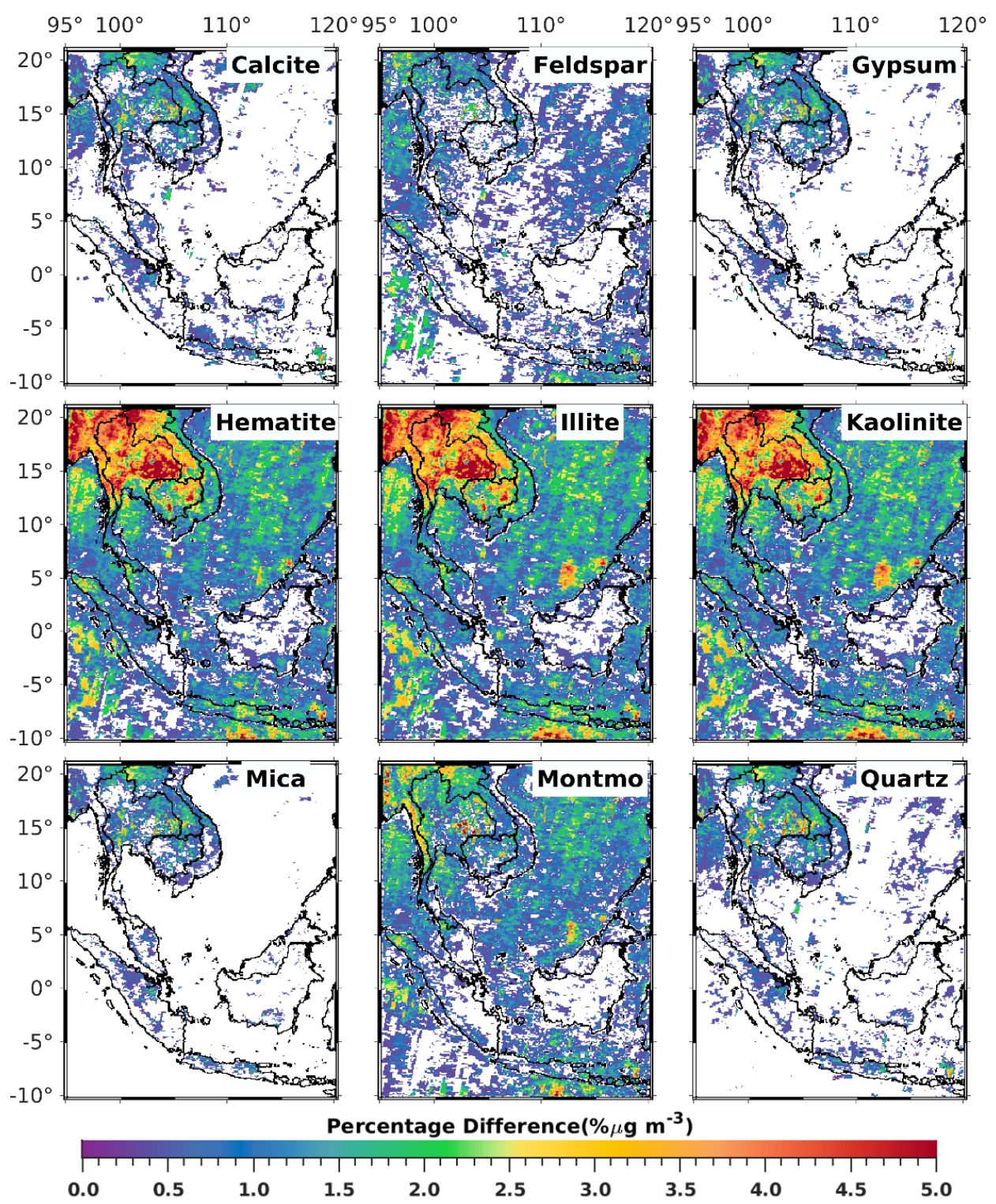

Figure 9. The average spatial distribution of deviation in the mineral concentration corresponding to a 50\% rise in AOD represents the model's sensitivity towards the variable aerosol load. 

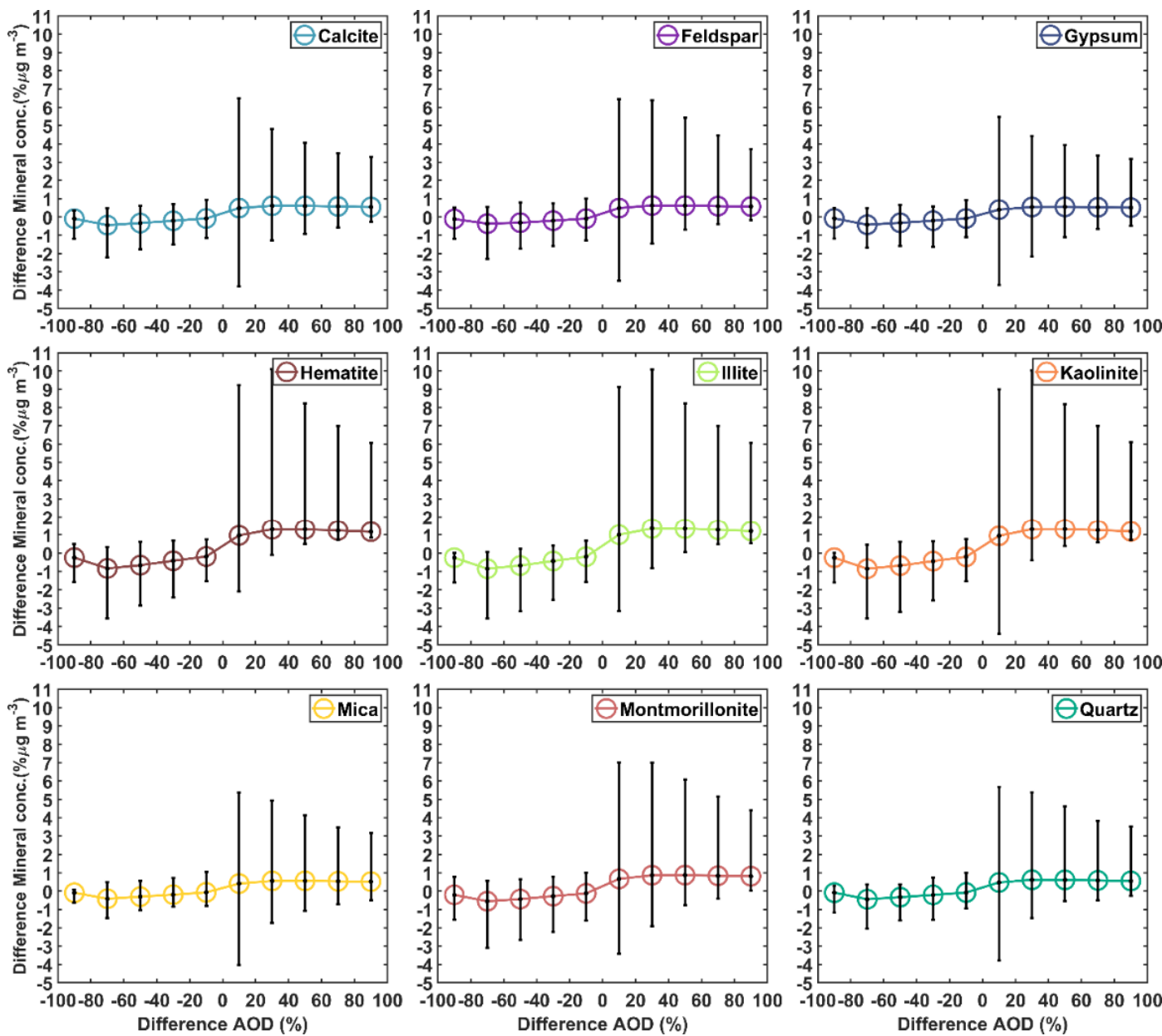

Figure 10. The average response of the dust-mineral retrieval with respect to the varying AOD (550 $\mathrm{nm}$ ) values in steps between $\pm 10-90 \%$.

Our computations (Figure 11) show the largest deviation of $\sim 14 \%$ (in total) for the finesized aerosols $(<2 \mu \mathrm{m})$ under loading at $+90 \%$ AOD over terrestrial regions. In comparison, the deviation was $\sim 8.5 \%$ over marine areas, whereas it was $\sim 0.85 \%$ over the terrestrial region and $\sim 1.7 \%$ over marine areas for coarse silt particles $(>2 \mu \mathrm{m})$. Nevertheless, the composition of the minerals in the dust and the particle size spectrum remains the same, as the AOD spectral shape was retained and not altered.
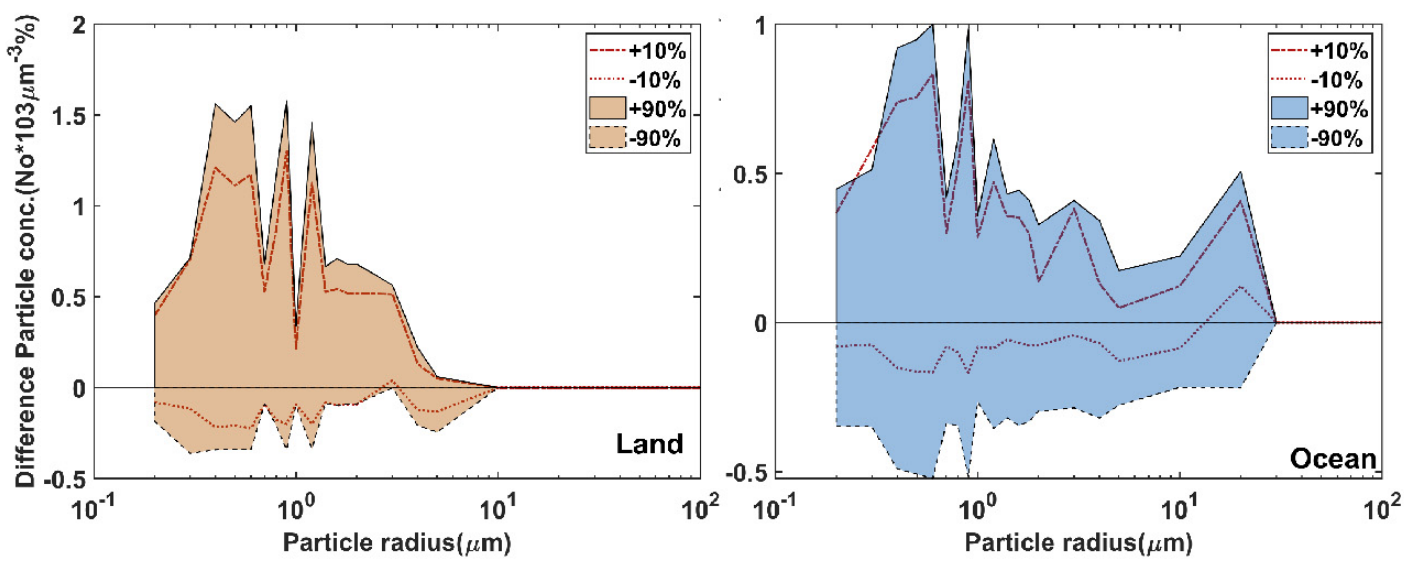

Figure 11. The average response of the mineral particle size distribution with respect to the varying AOD (550 nm) values in steps between $\pm 10-90 \%$. 


\section{Discussions}

Southeast Asia hosts mixtures of a wide range of atmospheric aerosols originating from various natural and anthropogenic sources, such as volcanic eruptions, industry, mobile sources, biofuel, deforestation, and biomass burning [6]. Spatial heterogeneity observed in Figure 1a from clean marine areas to highly contaminated terrestrial regions is thus apparent. Biomass burning is common in the Southeast Asia region to remove the post-harvested crop residues and prepare fields for cultivation during the monsoon. The intense burning typically peaks during the dry season between January-April for Thailand, Vietnam, Cambodia, Myanmar, and Laos PDR, and July-October in Indonesia and Malaysia $[45,46]$. Hence, the satellite images of March demonstrate the burning generated haze in Thailand and nearby areas, whereas June and November images represent the clear non-dusty days (Figures 1-4). The AE presented in Figure 1b captures the spectral variation of AOD and is inversely proportional to the particle size according to classical Mie scattering theory. It identifies an ambient aerosol scene's dominating aerosol mode (fine or coarse) [47]. Therefore, $\mathrm{AE} \geq 1$ over the terrestrial regions indicates an abundance of fine particles, mainly from continental sources such as black carbon or sulfate. At the same time, $\mathrm{AE}<1$ over the marine areas represents the dominance of coarse particles such as sea salt from natural sea spray [47] and hygroscopic continental aerosols. The coarser silt particles $(>2 \mu \mathrm{m})$ prominent over terrestrial regions (Figure 5 ) in the immediate vicinity of their emission sources are short lived, and particles settle within a short distance, thereby causing localized effects. Conversely, the fine-sized clay particles $(<2 \mu \mathrm{m})$ observed over the region (Figure 5) have a greater residence time in the atmosphere, and hence they are subject to long-range transport [48]. Upon reaching the marine areas, these continental particles expand in size according to their hygroscopicity. The finest, insoluble particles with a diameter $<2.5 \mu \mathrm{m}$ are the most detrimental to health $[8,9]$.

Understanding the emission sources corresponding to different aerosol components is critical for air pollution control. Silicon (Si) and aluminum (Al) are the second- and third-most abundant element in the Earth's crust, and the dominant component of soil systems and dust [10]. The predominance of typical aluminosilicate minerals (phyllosilicates in Figure 2 and tectosilicates in Figure 3) discerned in MODIS-derived mineralogy is thus apparent. The calcite observed in our Southeast Asian region (Figure 4a) other than limestone bedrock is most likely formed from calcium oxalate in vegetation during biomass burning, which is transformed into calcium carbonate crystals during combustion [49,50]. Combustion-released calcium carbonate observed in dust mineralogy potentially plays a vital role in regulating the $\mathrm{pH}$ of precipitation in the region [51,52]. The major iron oxide species in mineral dust prevailing in the region are hematite and goethite (Figure $4 b$ ), whose relative abundances vary by source region [53]. Ferric minerals are essential components of lithogenic soil that control magnetic susceptibility [54]. Ferric oxide minerals in atmospheric dust are efficient at absorbing solar radiation at UV and visible wavelengths [30], and can thus influence atmospheric temperatures and accelerate the melting of snow and ice by diminishing surface albedo [55]. Iron aerosols can also stimulate marine phytoplankton productivity $[3,56]$. Emitted sulfur during biomass burning is oxidized to sulfur dioxide $\left(\mathrm{SO}_{2}\right)$ and consequently undergoes chemical reactions to produce sulfate PM in the atmosphere [57]. Field measurements of smoke released from biomass burning over Southeast Asia are well-documented in the literature $[58,59]$. Hence, the observation of sulfurized gypsum in Figure 4c released due to biomass burning is apparent. Significant amounts of sulfate aerosols released during biomass burning are hygroscopic in nature and act as a smoke tracer for the region [46,60]. Additionally, carbonate crystals formed during combustion are also chief precursors of secondary gypsum [57]. Hence, the minerals (illite, kaolinite, montmorillonite, feldspar, mica, quartz, calcite, hematite, and gypsum) and the metals $(\mathrm{Al}, \mathrm{Ca}, \mathrm{Fe}$, and $\mathrm{Mg}$ ) considered in this study are either aerosolized during biomass burning or are introduced by secondary production during the fire.

Statistical significance, high correlations and a strong relationship observed between the mineral and metal concentrations (Figure 6) suggest that the percentage of the derived 
mineral composition matches the in situ measured metal composition. This indicates that the proposed model can identify the chemical (mineral) composition both quantitatively and qualitatively. The highest contributors are phyllosilicates and hematite. Satellite retrievals of UVAI from OMI are extensively utilized for identifying the source of dust aerosols and combustion of biomass and fossil fuels [45,61]. The high values of MODISderived mineral concentrations noticed during a haze event overlap with the peak UVAI values (Figure 7) due to increased activity of absorbing aerosols emitted from biomass burning and dust particles. These findings agree with the previous investigations by [62] over Cairo and [63] over Durban. This reflects that the model precisely captures the location and areal extent of dust and smoke plumes during a haze event. UVAI is an excellent marker for carbonaceous absorbing aerosols from biomass burning. We noticed significantly high UVAI values ranging from 1.0 to 2.0 for forest and plantation/peatland mixed fires. The mineral composition model developed in this study is sufficiently flexible to be applied to both in situ and satellite measurements. Therefore, AERONET-measured AOD and AE from Chiang Rai, Bangkok, and Singapore were used to derive the mineral concentrations using the proposed model and compared with their respective MODIS counterparts. Close distribution along the 1:1 reference line between the AERONET and MODIS-derived minerals (Figure 8) signifies less scatter and provides us the confidence of a robust correlation. Lower values of the Y-intercept indicate a strong relationship. This suggests that the proposed model is robust and stable enough in managing the uncertainties involved in satellite derivations of AOD and AE quite well without altering the shape of the AOD spectra and composition of the minerals.

Appropriate mineral derivations from the modeling approach discussed here rely on the accurate AOD and AE values. Deviations in AOD or AE will change the shape of the AOD spectra, yielding inaccurate estimates of mineral concentrations. We must also acknowledge that uncertainty is an inherent property of satellite AOD derivations and cannot be entirely eliminated and will likely propagate to further derivations [64], i.e., to mineral concentrations in our case. An analysis of uncertainty involved in mineral derivations due to the deviations in AOD and AE (Figures 9-11) is, therefore, a beneficial measure to determine the model's performance. The sensitivity of the retrieval of the mineral composition is negligible for low aerosol loading and weakly and non-absorbing aerosols (Figures 9 and 10). However, uncertainties associated with space-borne AOD derivations for absorbing aerosol analogs and unevenly shaped dust particles or mixtures containing aerosols from combustion sources and urban regions cannot be neglected [44]. Hence, more attention should be provided to dense and elevated aerosol layers caused by fires or extreme dust events. This appears reasonable, as the most sensitive minerals identified in our study are phyllosilicates and ferric oxides (Figure 9). They prevail in copious amounts over the entire region (Figures 3 and 4). During combustion events (in the vicinity of smoke), fine and coarse iron-rich silicate dust is mobilized by large fires. Remarkably, our analysis reveals that sensitivity to the mineral derivation remained $<10 \%$ even when the aerosol loading was varied by $\pm 90 \%$.

The purpose of the sensitivity analysis is to help us evaluate the uncertainties involved in the retrieval of each mineral based on the agreement between AERONET- and MODISderived AOD. Consequently, an uncertainty of $6.4 \%$ between AERONET-measured and MODIS-derived AOD (from Figure 8) corresponds to a $< \pm 2 \%$ deviation in mineral composition inversion from satellite using the proposed model (Figure 10). This demonstrates the robustness of the mineral inversion model and that the model is reliable enough for such mineral derivations without altering the composition (Figures 9 and 10) of mineral dust or its particle size spectrum (Figure 11).

\section{Conclusions}

This study investigates a cost-effective and feasible way of retrieving the spatial distribution of aerosols' particle size and mineral composition from satellite remote sensing across Southeast Asia. The smoke tracing minerals-calcite and gypsum-highlight the 
poor air quality over combustion-affected regions. High correlation with chemically analyzed metal and AERONET-derived mineral concentrations together with low uncertainties demonstrates the robustness and stability of the proposed model. Reasonable agreement with the OMI-derived dust, smoke, and non-absorbing aerosols signifies that the model can characterize the chemical, optical, and microphysical properties of aerosol mineralogy across large scales. Besides climatic effects, epidemiological and toxicological evidence of increased particulate matter levels is emerging as a significant cause of concern. The ability to measure aerosol composition from remote sensing will enable us to improve our understanding of the effects of aerosols on climate, which remains a significant source of uncertainty in our understanding of the climate system. We recommend that operational satellite derivations on aerosols include chemical composition to perform source apportionment and health risk assessment studies.

Author Contributions: This work was conceived of and planned by N.S. and R.D. Field data to validate the model were collected by R.D. and her lab associates. N.S parameterized the model. Satellite data were downloaded processed, and N.S performed the analysis. The manuscript was written and edited by N.S. and R.D. All authors have read and agreed to the published version of the manuscript.

Funding: This research received no external funding.

Data Availability Statement: MODIS Aqua and Terra from the LAADS DAAC's satellite data services (https: / / ladsweb.modaps.eosdis.nasa.gov / (last access: 1 June 2021)). AERONET data of the respective station was downloaded from http:/ / aeronet.gsfc.nasa.gov (last accessed on 1 June 2021). Aura Ozone Monitoring Instrument level 2 near UV Aerosol data product was downloaded from NASA's https:/ / disc.gsfc.nasa.gov / datasets/OMAERUV_003/ (last accessed on 1 June 2021). Analytical details of elemental concentration data are published in [32].

Acknowledgments: The in situ chemical analyses of aerosols were supported by a Singapore Ministry of Education (MOE) Tier 1 grant (MOE-NTU_RG125/16-(S)). We thank the students and lab associates who helped us with field logistics and sample collection. We thank the research groups of MODIS, AURA, and AERONET for providing the data. Constructive criticism by Patrick Martin and our anonymous reviewers improved an earlier draft of this manuscript.

Conflicts of Interest: The authors declare no conflict of interest.

\section{Appendix A}

Table A1. Adopted size distribution of mineral species and the sources of its derived complex refractive indices.

\begin{tabular}{|c|c|c|}
\hline Minerals & Particle Size (Diameter) & Source \\
\hline Illite & $0.4-2.0 \mu \mathrm{m}$ at an interval of $0.2 \mu \mathrm{m}(100 \%$ Clay $)$ & {$[65,66]$} \\
\hline Kaolinite & $0.4-2.0 \mu \mathrm{m}$ at an interval of $0.2 \mu \mathrm{m}(100 \%$ Clay $)$ & {$[65,66]$} \\
\hline Montmorillonite & $0.4-2.0 \mu \mathrm{m}$ at an interval of $0.2 \mu \mathrm{m}(100 \%$ Clay $)$ & {$[65,66]$} \\
\hline Hematite & $\begin{array}{c}0.4-2.0 \mu \mathrm{m} \text { at an interval of } 0.2 \mu \mathrm{m} \text { (100\%Clay) } \\
0.4-2.0 \mu \mathrm{m} \text { at an interval of } 0.4 \mu \mathrm{m} \text { (Clay) }\end{array}$ & [67] \\
\hline Quartz & $\begin{array}{l}4.0-10 \mu \mathrm{m} \text { at an interval of } 2 \mu \mathrm{m} \text { (Silt) } \\
20-50 \mu \mathrm{m} \text { at an interval of } 20 \mu \mathrm{m} \text { (Silt) } \\
0.4-2.0 \mu \mathrm{m} \text { at an interval of } 0.2 \mu \mathrm{m} \text { (Clay) }\end{array}$ & [68] \\
\hline Calcite & $\begin{array}{l}4.0-10 \mu \mathrm{m} \text { at an interval of } 2 \mu \mathrm{m} \text { (Silt) } \\
20-50 \mu \mathrm{m} \text { at an interval of } 20 \mu \mathrm{m} \text { (Silt) } \\
0.4-2.0 \mu \mathrm{m} \text { at an interval of } 0.2 \mu \mathrm{m} \text { (Clay) } \\
4.0-10 \mu \mathrm{m} \text { at an interval of } 2 \mu \mathrm{m} \text { (Silt) }\end{array}$ & {$[66,69,70]$} \\
\hline Feldspar & $\begin{array}{c}20-50 \mu \mathrm{m} \text { at an interval of } 20 \mu \mathrm{m} \text { (Silt) } \\
80-100 \mu \mathrm{m} \text { at an interval of } 20 \mu \mathrm{m} \text { (Sand) } \\
100-500 \mu \mathrm{m} \text { at an interval of } 250 \mu \mathrm{m} \text { (Sand) } \\
0.4-2.0 \mu \mathrm{m} \text { at an interval of } 0.2 \mu \mathrm{m} \text { (Clay) } \\
4.0-10 \mu \mathrm{m} \text { at an interval of } 2 \mu \mathrm{m} \text { (Silt) }\end{array}$ & [65] \\
\hline Gypsum & $\begin{array}{c}20-50 \mu \mathrm{m} \text { at an interval of } 20 \mu \mathrm{m} \text { (Silt) } \\
80-100 \mu \mathrm{m} \text { at an interval of } 20 \mu \mathrm{m} \text { (Sand) } \\
100-500 \mu \mathrm{m} \text { at an interval of } 250 \mu \mathrm{m} \text { (Sand) }\end{array}$ & [70] \\
\hline Mica & $\begin{array}{l}2.0-10 \mu \mathrm{m} \text { at an interval of } 2 \mu \mathrm{m} \text { (Silt) } \\
20-50 \mu \mathrm{m} \text { at an interval of } 20 \mu \mathrm{m} \text { (Silt) }\end{array}$ & [65] \\
\hline
\end{tabular}


Table A2. The chemical formula of the modeled minerals.

\begin{tabular}{|c|c|c|c|c|c|}
\hline Mineral & Empirical Formula & $\mathrm{Al} \%$ & $\mathrm{Fe} \%$ & $\mathrm{Ca} \%$ & $\mathbf{M g} \%$ \\
\hline Illite & $\begin{array}{c}(\mathrm{K}, \mathrm{H} 3 \mathrm{O})(\mathrm{Al}, \mathrm{Mg}, \mathrm{Fe}) 2(\mathrm{Si}, \mathrm{Al}) \\
4 \mathrm{O} 10[(\mathrm{OH}) 2,(\mathrm{H} 2 \mathrm{O})]\end{array}$ & 9 & 1.4 & & 1.9 \\
\hline Kaolinite & $\mathrm{Al} 2 \mathrm{Si} 2 \mathrm{O} 5(\mathrm{OH}) 4$ & 20.9 & & & \\
\hline Montmorillonite & $\begin{array}{l}\mathrm{Na} 0.2 \mathrm{Ca} 0.1 \mathrm{Al} 2 \mathrm{Si} 4 \mathrm{O} 10 \\
(\mathrm{OH}) 2(\mathrm{H} 2 \mathrm{O}) 10\end{array}$ & 9.8 & & 0.7 & \\
\hline Hematite & $\mathrm{Fe} 2 \mathrm{O} 3$ & & 69.9 & & \\
\hline Quartz & $\mathrm{SiO} 2$ & & & & \\
\hline Calcite & $\mathrm{CaCO} 3$ & & & 40 & \\
\hline Feldspar & $(\mathrm{Na}, \mathrm{Ca}, \mathrm{K})(\mathrm{Al}, \mathrm{Si}) 4 \mathrm{O} 8$ & 0 & 0 & 0 & 0 \\
\hline $\begin{array}{l}\text { Potassium } \\
\text { Feldspar }\end{array}$ & KAlSi3O8 & 9.7 & & & \\
\hline Albite & $\mathrm{NaAlSi} 3 \mathrm{O} 8$ & 10.8 & & 0.8 & \\
\hline Anorthite & $\mathrm{CaAl} 2 \mathrm{Si} 2 \mathrm{O} 8$ & 19 & & 13.7 & \\
\hline $\begin{array}{l}\text { Gypsum } \\
\text { Mica }\end{array}$ & CaSO4. $2 \mathrm{H} 2 \mathrm{O}$ & & & 23.3 & \\
\hline Biotite & $\mathrm{K}(\mathrm{Mg}, \mathrm{Fe}++) 3[\mathrm{AlSi} 3 \mathrm{O} 10(\mathrm{OH}, \mathrm{F}) 2$ & 6.2 & 6.4 & & 14 \\
\hline Muscovite & $\mathrm{KAl} 2(\mathrm{Si} 3 \mathrm{Al}) \mathrm{O} 10(\mathrm{OH}, \mathrm{F}) 2$ & 20.3 & & & \\
\hline Phlogopite & $\mathrm{KMg} 3(\mathrm{Si} 3 \mathrm{Al}) \mathrm{O} 10(\mathrm{~F}, \mathrm{OH}) 2$ & 6.4 & & & 17.4 \\
\hline Lepidolite & KLi2AlSi4O10F(OH) & 7 & & & \\
\hline Paragonite & $\mathrm{NaAl3Si3O10}(\mathrm{OH}) 2$ & 21.2 & & & \\
\hline Glauconite & $\begin{array}{c}(\mathrm{K}, \mathrm{Na})(\mathrm{Fe}+++, \mathrm{Al}, \mathrm{Mg}) 2(\mathrm{Si}, \mathrm{Al}) \\
4 \mathrm{O} 10(\mathrm{OH}) 2\end{array}$ & 1.9 & 19.6 & & 2.3 \\
\hline Margarite & $\mathrm{CaAl} 2(\mathrm{Al} 2 \mathrm{Si} 2) \mathrm{O} 10(\mathrm{OH}) 2$ & 27.1 & & 10.1 & \\
\hline Clintonite & $\mathrm{Ca}(\mathrm{Mg}, \mathrm{Al}) 3(\mathrm{Al} 3 \mathrm{Si}) \mathrm{O} 10(\mathrm{OH}) 2$ & 22.1 & & 9.6 & 12.9 \\
\hline
\end{tabular}

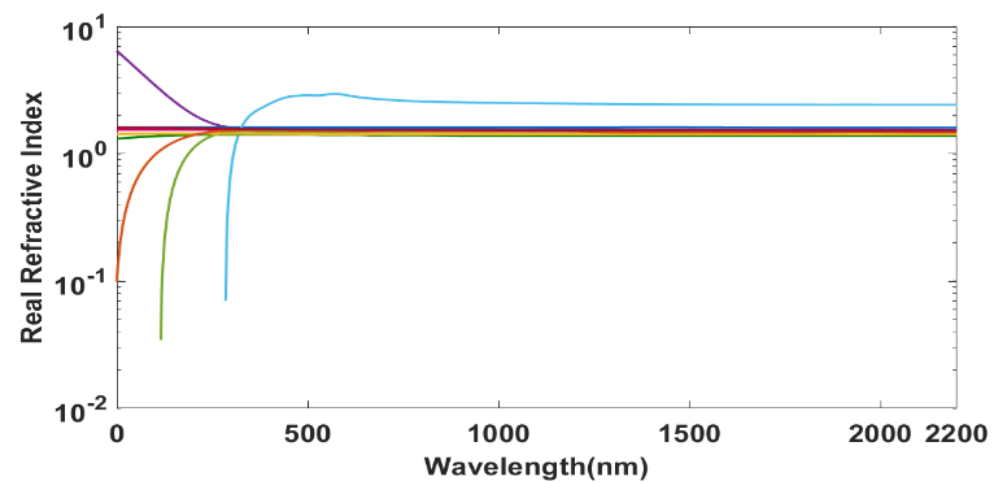

(a)

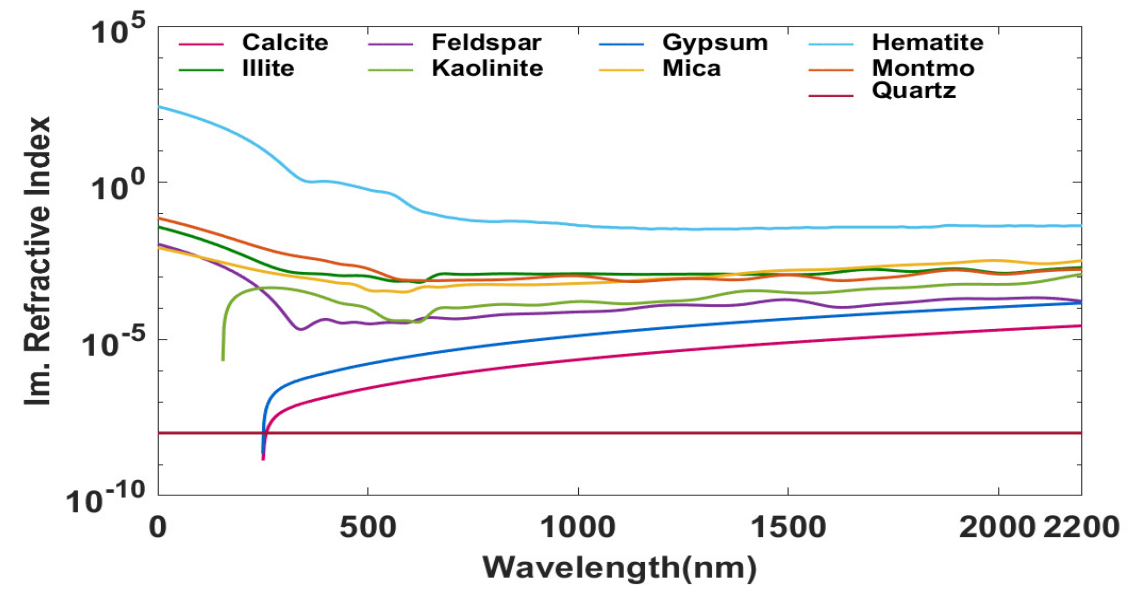

(b)

Figure A1. (a) Real (n) and (b) imaginary (k) parts of the complex refractive index within the spectral range 0-2200 $\mathrm{nm}$ for individual minerals used in the model. 


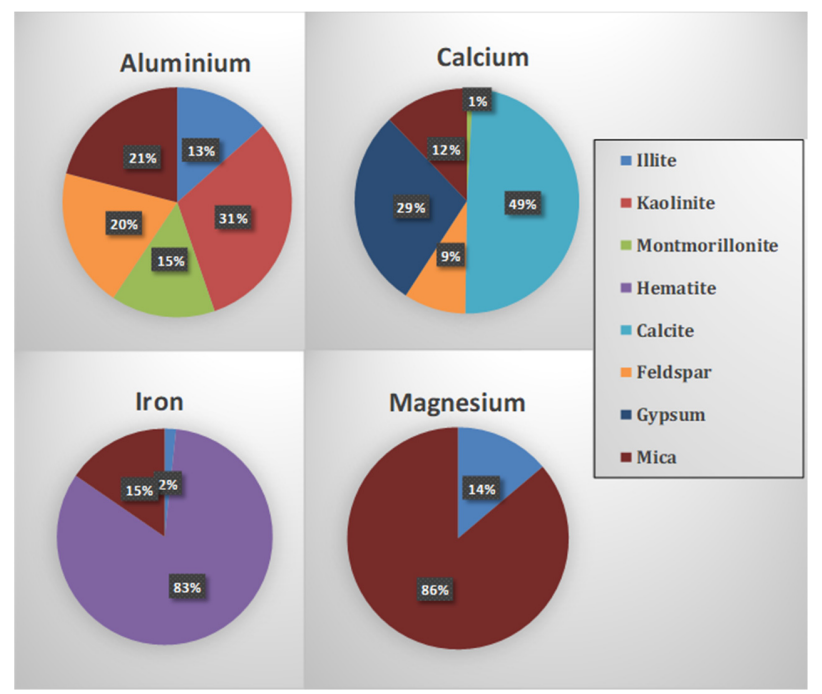

Figure A2. Relative distribution of aluminum, calcium, iron, and magnesium for the minerals used in the model.
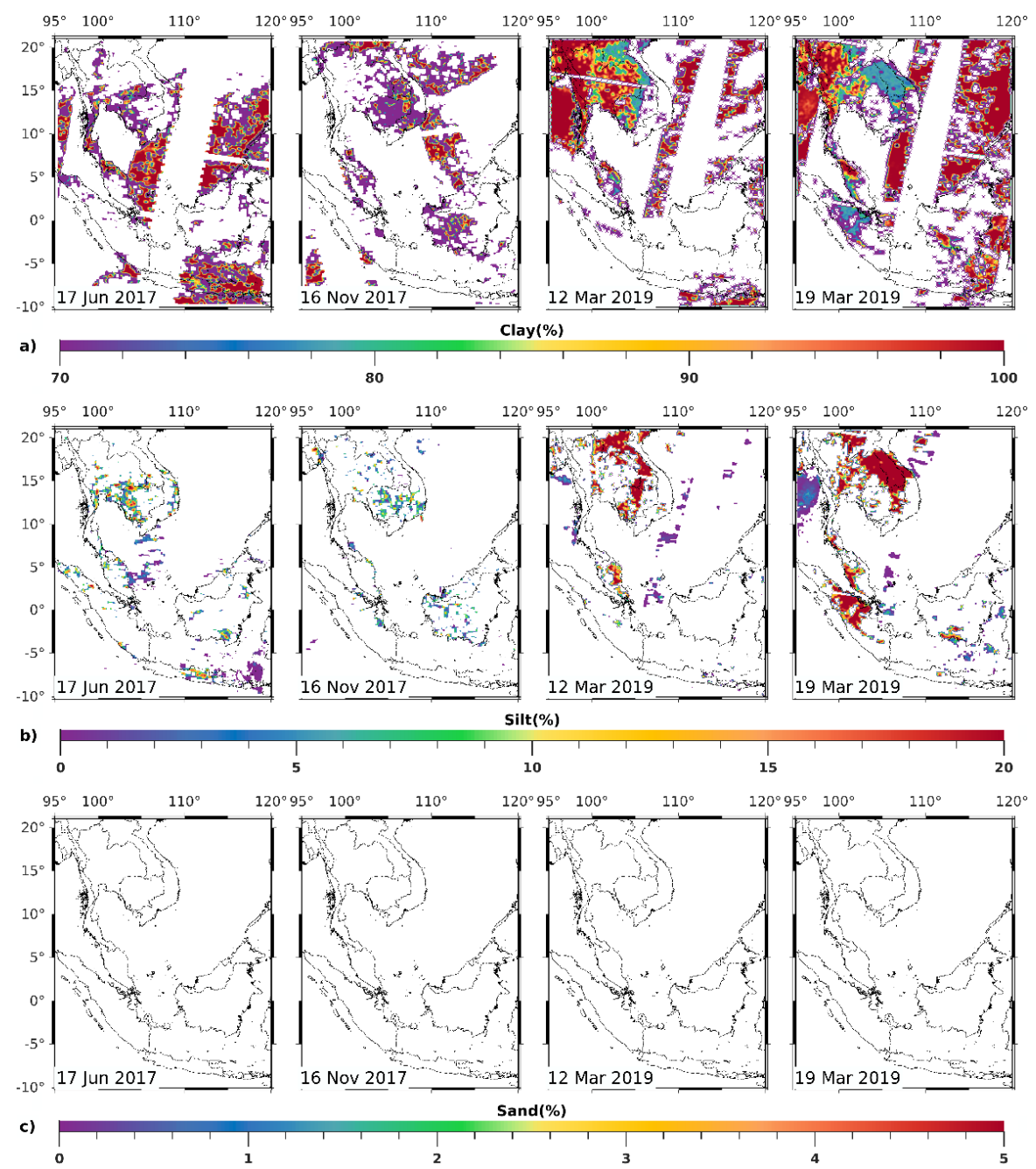

Figure A3. Spatial distribution of MODIS-derived percentage of (a) clay mineral particles $(<2 \mu \mathrm{m}$ diameter); (b) silt mineral particles (2-50 $\mu \mathrm{m}$ diameter); (c) sand mineral particles ( $>50 \mu \mathrm{m}$ diameter) for Southeast Asia region corresponding to two non-dusty and two dusty days from the validation dataset. 


\section{References}

1. Boucher, O.; Randall, D.; Artaxo, P.; Bretherton, C.; Feingold, G.; Forster, P.; Kerminen, V.-M.; Kondo, Y.; Liao, H.; Lohmann, U.; et al. Clouds and Aerosols. In Climate Change 2013: The Physical Science Basis. Contribution of Working Group I to the Fifth Assessment Report of the Intergovernmental Panel on Climate Change; Stocker, T.F., Qin, D., Plattner, G.-K., Tignor, M., Allen, S.K., Boschung, J., Nauels, A., Xia, Y., Bex, V., et al., Eds.; Cambridge University Press: Cambridge, UK; New York, NY, USA, 2013.

2. Aciego, S.M.; Riebe, C.; Hart, S.C.; Blakowski, M.; Carey, C.J.; Aarons, S.M.; Dove, N.; Botthoff, J.K.; Sims, K.W.W.; Aronson, E.L. Dust outpaces bedrock in nutrient supply to montane forest ecosystems. Nat. Commun. 2017, 8, 14800. [CrossRef] [PubMed]

3. Mahowald, N.M.; Scanza, R.; Brahney, J.; Goodale, C.L.; Hess, P.G.; Moore, J.K.; Neff, J. Aerosol Deposition Impacts on Land and Ocean Carbon Cycles. Curr. Clim. Chang. Rep. 2017, 3, 16-31. [CrossRef]

4. Tegen, I.; Schepanski, K. Climate Feedback on Aerosol Emission and Atmospheric Concentrations. Curr. Clim. Chang. Rep. 2018, 4, 1-10. [CrossRef]

5. Lelieveld, J. Clean air in the Anthropocene. Faraday Discuss. 2017, 200, 693-703. [CrossRef] [PubMed]

6. $\quad$ Reid, C.E.; Brauer, M.; Johnston, F.H.; Jerrett, M.; Balmes, J.R.; Elliott, C.T. Critical Review of Health Impacts of Wildfire Smoke Exposure. Environ. Health Perspect. 2016, 124, 1334-1343. [CrossRef]

7. Schulze, F.; Gao, X.; Virzonis, D.; Damiati, S.; Schneider, M.R.; Kodzius, R. Air Quality Effects on Human Health and Approaches for Its Assessment through Microfluidic Chips. Genes 2017, 8, 244. [CrossRef] [PubMed]

8. Cohen, A.J.; Brauer, M.; Burnett, R.; Anderson, H.R.; Frostad, J.; Estep, K.; Balakrishnan, K.; Brunekreef, B.; Dandona, L.; Dandona, R.; et al. Estimates and 25-year trends of the global burden of disease attributable to ambient air pollution: An analysis of data from the Global Burden of Diseases Study. Lancet 2017, 389, 1907-1918. [CrossRef]

9. Xing, Y.-F.; Xu, Y.-H.; Shi, M.-H.; Lian, Y.-X. The impact of PM2.5 on the human respiratory system. J. Thorac. Dis. 2016, 8, E69-E74.

10. Perlwitz, J.P.; García-Pando, C.P.; Miller, R.L. Predicting the mineral composition of dust aerosols—Part 1: Representing key processes. Atmos. Chem. Phys. 2015, 15, 11593-11627. [CrossRef]

11. Scanza, R.A.; Mahowald, N.; Ghan, S.; Zender, C.S.; Kok, J.F.; Liu, X.; Zhang, Y.; Albani, S. Modeling dust as component minerals in the Community Atmosphere Model: Development of framework and impact on radiative forcing. Atmos. Chem. Phys. 2015, 15, 537-561. [CrossRef]

12. Xie, Y.; Li, Z.; Li, D.; Xu, H.; Li, K. Aerosol Optical and Microphysical Properties of Four Typical Sites of SONET in China Based on Remote Sensing Measurements. Remote Sens. 2015, 7, 9928-9953. [CrossRef]

13. García-Pando, C.P.; Miller, R.L.; Perlwitz, J.P.; Rodríguez, S.; Prospero, J.M. Predicting the mineral composition of dust aerosols: Insights from elemental composition measured at the Izaña Observatory. Geophys. Res. Lett. 2016, 43, 10-520.

14. Hu, Z.; Zhao, C.; Huang, J.; Leung, L.R.; Qian, Y.; Yu, H.; Kalashnikova, O.V. Trans-Pacific transport and evolution of aerosols: Evaluation of quasi-global WRF-Chem simulation with multiple obser-vations. Geosci. Model Dev. 2016, 9, 1725-1746. [CrossRef]

15. Baumgardner, D.; Brenguier, J.L.; Bucholtz, A.; Coe, H.; DeMott, P.; Garrett, T.J.; Chuang, P. Airborne instruments to measure atmospheric aerosol particles, clouds and radiation: A cook's tour of mature and emerging technology. Atmos. Res. 2011, 102, 10-29. [CrossRef]

16. Formenti, P.; Schütz, L.; Balkanski, Y.; Desboeufs, K.; Ebert, M.; Kandler, K.; Petzold, A.; Scheuvens, D.; Weinbruch, S.; Zhang, D. Recent progress in understanding physical and chemical properties of African and Asian mineral dust. Atmos. Chem. Phys. 2011, 11, 8231-8256. [CrossRef]

17. Dubovik, O.; Sinyuk, A.; Lapyonok, T.; Holben, B.N.; Mishchenko, M.; Yang, P.; Eck, T.F.; Volten, H.; Muñoz, O.; Veihelmann, B.; et al. Application of spheroid models to account for aerosol particle nonsphericity in remote sensing of desert dust. J. Geophys. Res. Atmos. 2006, 111. [CrossRef]

18. Kaufman, Y.J.; Gitelson, A.; Karnieli, A.; Ganor, E.; Fraser, R.S.; Nakajima, T.; Mattoo, S.; Holben, B.N. Size distribution and scattering phase function of aerosol particles retrieved from sky brightness measurements. J. Geophys. Res. Earth Surf. 1994, 99, 10341-10356. [CrossRef]

19. Li, Z.; Gu, X.; Wang, L.; Li, D.; Xie, Y.; Li, K.; Dubovik, O.; Schuster, G.; Goloub, P.; Zhang, Y.; et al. Aerosol physical and chemical properties retrieved from ground-based remote sensing measurements during heavy haze days in Beijing winter. Atmos. Chem. Phys. 2013, 13, 10171-10183. [CrossRef]

20. Schuster, G.L.; Dubovik, O.; Arola, A. Remote sensing of soot carbon-Part 1: Distinguishing different absorbing aerosol species. Atmos. Chem. Phys. 2016, 16, 1565-1585. [CrossRef]

21. Levy, R.C.; Mattoo, S.; Munchak, L.A.; Remer, L.A.; Sayer, A.M.; Patadia, F.; Hsu, N.C. The Collection 6 MODIS aerosol products over land and ocean. Atmos. Meas. Tech. 2013, 6, 2989-3034. [CrossRef]

22. Hsu, N.C.; Jeong, M.-J.; Bettenhausen, C.; Sayer, A.M.; Hansell, R.; Seftor, C.S.; Huang, J.; Tsay, S.-C. Enhanced Deep Blue aerosol retrieval algorithm: The second generation. J. Geophys. Res. Atmos. 2013, 118, 9296-9315. [CrossRef]

23. Wei, J.; Peng, Y.; Guo, J.; Sun, L. Performance of MODIS Collection 6.1 Level 3 aerosol products in spatial-temporal variations over land. Atmos. Environ. 2019, 206, 30-44. [CrossRef]

24. Wei, J.; Sun, L.; Peng, Y.; Wang, L.; Zhang, Z.; Bilal, M.; Ma, Y. An Improved High-Spatial-Resolution Aerosol Retrieval Algorithm for MODIS Images Over Land. J. Geo-Phys. Res. Atmos. 2018, 123, 12291-12307. [CrossRef]

25. Torres, O.; Tanskanen, A.; Veihelmann, B.; Ahn, C.; Braak, R.; Bhartia, P.; Veefkind, P.; Levelt, P.P. Aerosols and surface UV products from Ozone Monitoring Instrument observations: An overview. J. Geophys. Res. Earth Surf. 2007, 112, D24S47. [CrossRef] 
26. Journet, E.; Balkanski, Y.; Harrison, S.P. A new data set of soil mineralogy for dust-cycle modeling. Atmos. Chem. Phys. 2014, 14, 3801-3816. [CrossRef]

27. Nickovic, S.; Vukovic, A.; Vujadinovic, M.; Djurdjevic, V.; Pejanovic, G. Technical Note: High-resolution mineralogical database of dust-productive soils for atmospheric dust modeling. Atmos. Chem. Phys. 2012, 12, 845-855. [CrossRef]

28. Miller, R.L.; Cakmur, R.V.; Perlwitz, J.; Geogdzhayev, I.V.; Ginoux, P.; Koch, D.; Kohfeld, K.; Prigent, C.; Ruedy, R.; Schmidt, G.; et al. Mineral dust aerosols in the NASA Goddard Institute for Space Sciences ModelE atmospheric general circulation model. J. Geophys. Res. Earth Surf. 2006, 111, D06208. [CrossRef]

29. Kalashnikova, O.; Sokolik, I. Modeling the radiative properties of nonspherical soil-derived mineral aerosols. J. Quant. Spectrosc. Radiat. Transf. 2004, 87, 137-166. [CrossRef]

30. Sokolik, I.N.; Toon, O.B. Incorporation of mineralogical composition into models of the radiative properties of mineral aerosol from UV to IR wavelengths. J. Geophys. Res. Earth Surf. 1999, 104, 9423-9444. [CrossRef]

31. Shen, Z.; Cao, J.; Zhang, X.-Y.; Arimoto, R.; Ji, J.; Balsam, W.; Wang, Y.; Zhang, R.; Li, X. Spectroscopic analysis of iron-oxide minerals in aerosol particles from northern China. Sci. Total Environ. 2006, 367, 899-907. [CrossRef]

32. Kayee, J.; Sompongchaiyakul, P.; Sanwlani, N.; Bureekul, S.; Wang, X.; Das, R. Metal Concentrations and Source Apportionment of PM2.5 in Chiang Rai and Bangkok, Thailand during a Biomass Burning Season. ACS Earth Space Chem. 2020, 4, 1213-1226. [CrossRef]

33. Kayee, J.; Bureekul, S.; Sompongchaiyakul, P.; Wang, X.; Das, R. Sources of atmospheric lead (Pb) after quarter century of phasing out of leaded gasoline in Bangkok, Thailand. Atmos. Environ. 2021, 253, 118355. [CrossRef]

34. Rudnick, R.L.; Gao, S. Composition of the Continental Crust. In Treatise on Geochemistry; Rudnick, R.L., Holland, H.D., Turekian, K.K., Eds.; Elsevier: Amsterdam, The Netherlands, 2003; pp. 1-64.

35. Chew, B.N.; Campbell, J.; Reid, J.S.; Giles, D.; Welton, E.J.; Salinas, S.V.; Liew, S.C. Tropical cirrus cloud contamination in sun photometer data. Atmos. Environ. 2011, 45, 6724-6731. [CrossRef]

36. Ångström, A. Techniques of Determinig the Turbidity of the Atmosphere. Tellus 1961, 13, 214-223. [CrossRef]

37. King, M.; Byrne, D.M.; Herman, B.M.; Reagan, J.A. Aerosol Size Distributions Obtained by Inversions of Spectral Optical Depth Measurements. J. Atmos. Sci. 1978, 35, 2153-2167. [CrossRef]

38. Almeida, D.C.; Koepke, P.; Shettle, E. Atmos. Aerosols Global Clima-tology and Radiative Characteristics; A. Deepak Publishing: Hampton, VA, USA, 1991

39. Wang, M.; Su, J.; Li, X.; Wang, C.; Ge, J. Parameterization of The Single-Scattering Properties of Dust Aerosols in Radiative Flux Calculations. Atmosphere 2019, 10, 728. [CrossRef]

40. Yu, X.; Shi, Y.; Wang, T.; Sun, X. Dust-concentration measurement based on Mie scattering of a laser beam. PLoS ONE 2017, 12, e0181575. [CrossRef]

41. Lawson, C.L.; Hanson, R.J. Solving Least Squares Problems; Prentice-Hall: Englewood Cliffs, NJ, USA, 1974.

42. Tripathi, M.K.; Govil, H. Evaluation of AVIRIS-NG hyperspectral images for mineral identification and mapping. Heliyon 2019, 5, e02931. [CrossRef]

43. van der Meer, F.D.; van der Werff, H.M.A.; van Ruitenbeek, F.J.A.; Hecker, C.A.; Bakker, W.H.; Noomen, M.F.; van der Meijde, M.; Carranza, E.J.M.; de Smeth, J.B.; Woldai, T. Multi- and hyperspectral geologic remote sensing: A review. Int. J. Appl. Earth Obs. Geoinf. 2012, 14, 112-128. [CrossRef]

44. Kahn, R.A.; Gaitley, B.J.; Garay, M.J.; Diner, D.J.; Eck, T.F.; Smirnov, A.; Holben, B.N. Multiangle Imaging SpectroRadiometer global aerosol product assessment by comparison with the Aerosol Robotic Network. J. Geophys. Res. Earth Surf. 2010, 115, 23. [CrossRef]

45. Vadrevu, K.P.; Lasko, K.; Giglio, L.; Justice, C. Vegetation fires, absorbing aerosols and smoke plume characteristics in diverse biomass burning regions of Asia. Environ. Res. Lett. 2015, 10, 105003. [CrossRef]

46. Reid, J.S.; Hyer, E.J.; Johnson, R.S.; Holben, B.N.; Yokelson, R.; Zhang, J.; Campbell, J.; Christopher, S.A.; Di Girolamo, L.; Giglio, L.; et al. Observing and understanding the Southeast Asian aerosol system by remote sensing: An initial review and analysis for the Seven Southeast Asian Studies (7SEAS) program. Atmos. Res. 2013, 122, 403-468. [CrossRef]

47. Eck, T.F.; Holben, B.N.; Reid, J.S.; Dubovik, O.; Smirnov, A.; O’Neill, N.T.; Slutsker, I.; Kinne, S. Wavelength Dependence of the Optical Depth of Biomass Burning, Urban, and Desert Dust Aerosols. J. Geophys. Res. Atmos. 1999, 104, 31333-31349. [CrossRef]

48. Satheesh, S.K.; Moorthy, K.K.; Babu, S.S.; Vinoj, V.; Nair, V.S.; Beegum, N.; Dutt, C.B.S.; Alappattu, D.P.; Kunhikrishnan, P.K Vertical structure and horizontal gradients of aerosol extinction coefficients over coastal India inferred from airborne lidar measurements during the Integrated Campaign for Aerosol, Gases and Radiation Budget (ICARB) field campaign. J. Geophys. Res. Earth Surf. 2009, 114, D05204. [CrossRef]

49. Iglesias, T.; Cala, V.; Gonzalez, J. Mineralogical and chemical modifications in soils affected by a forest fire in the Mediterranean area. Sci. Total Environ. 1997, 204, 89-96. [CrossRef]

50. Ulery, A.L.; Graham, R.C.; Amrhein, C. Wood-Ash Composition and Soil Ph Following Intense Burning. Soil Sci. 1993, 156, 358-364. [CrossRef]

51. Kumar, B.; Rai, S.P.; Kumar, U.S.; Verma, S.K.; Garg, P.; Kumar, S.V.V.; Jaiswal, R.; Purendra, B.K.; Pande, N.G. Isotopic characteristics of Indian precipitation. Water Resour. Res. 2010, 46. [CrossRef]

52. Xu, Z.; Wu, Y.; Liu, W.-J.; Liang, C.-S.; Ji, J.; Zhao, T.; Zhang, X. Chemical composition of rainwater and the acid neutralizing effect at Beijing and Chizhou city, China. Atmos. Res. 2015, 164, 278-285. [CrossRef] 
53. Formenti, P.; Caquineau, S.; Chevaillier, S.; Klaver, A.; Desboeufs, K.; Rajot, J.L.; Belin, S.; Briois, V. Dominance of goethite over hematite in iron oxides of mineral dust from Western Africa: Quantitative partitioning by X-ray absorption spectroscopy. J. Geophys. Res. Atmos. 2014, 119, 12740-12754. [CrossRef]

54. Shi, Z.; Krom, M.D.; Jickells, T.D.; Bonneville, S.; Carslaw, K.S.; Mihalopoulos, N.; Baker, A.R.; Benning, L.G. Impacts on iron solubility in the mineral dust by processes in the source region and the atmosphere: A review. Aeolian Res. 2012, 5, 21-42. [CrossRef]

55. Reynolds, R.L.; Goldstein, H.L.; Moskowitz, B.M.; Bryant, A.C.; Skiles, S.M.; Kokaly, R.F.; Flagg, C.B.; Yauk, K.; Berquó, T.; Breit, G.; et al. Composition of dust deposited to snow cover in the Wasatch Range (Utah, USA): Controls on radiative properties of snow cover and comparison to some dust-source sediments. Aeolian Res. 2014, 15, 73-90. [CrossRef]

56. Jickells, T.D.; An, Z.S.; Andersen, K.K.; Baker, A.R.; Bergametti, G.; Brooks, N.; Cao, J.J.; Boyd, P.W.; Duce, R.A.; Hunter, K.A.; et al. Global Iron Connections Between Desert Dust, Ocean Biogeochemistry, and Climate. Science 2005, 308, 67-71. [CrossRef]

57. Takahashi, Y.; Miyoshi, T.; Higashi, M.; Kamioka, H.; Kanai, Y. Neutralization of Calcite in Mineral Aerosols by Acidic Sulfur Species Collected in China and Japan Studied by Ca K-edge X-ray Absorption Near-Edge Structure. Environ. Sci. Technol. 2009, 43, 6535-6540. [CrossRef] [PubMed]

58. See, S.W.; Balasubramanian, R.; Rianawati, E.; Karthikeyan, S.; Streets, D.G. Characterization and Source Apportionment of Particulate Matter $\leq 2.5 \mu \mathrm{m}$ in Sumatra, Indonesia, during a Recent Peat Fire Episode. Environ. Sci. Technol. 2007, 41, 3488-3494. [CrossRef] [PubMed]

59. Betha, R.; Pradani, M.; Lestari, P.; Joshi, U.M.; Reid, J.; Balasubramanian, R. Chemical speciation of trace metals emitted from Indonesian peat fires for health risk assessment. Atmos. Res. 2013, 122, 571-578. [CrossRef]

60. Lin, N.-H.; Tsay, S.-C.; Maring, H.B.; Yen, M.-C.; Sheu, G.-R.; Wang, S.-H.; Chi, K.H.; Chuang, M.-T.; Ou-Yang, C.-F.; Fu, J.; et al. An overview of regional experiments on biomass burning aerosols and related pollutants in Southeast Asia: From BASE-ASIA and the Dongsha Experiment to 7-SEAS. Atmos. Environ. 2013, 78, 1-19. [CrossRef]

61. Hammer, M.S.; Martin, R.V.; van Donkelaar, A.; Buchard, V.; Torres, O.; Ridley, D.A.; Spurr, R.J.D. Interpreting the ultraviolet aerosol index observed with the OMI satellite instrument to understand absorption by organic aerosols: Implications for atmospheric oxidation and direct radiative effects. Atmos. Chem. Phys. 2016, 16, 2507-2523. [CrossRef]

62. Marey, H.S.; Gille, J.C.; El-Askary, H.M.; Shalaby, E.A.; El-Raey, M.E. Aerosol climatology over Nile Delta based on MODIS, MISR and OMI satellite data. Atmos. Chem. Phys. 2011, 11, 10637-10648. [CrossRef]

63. Kumar, K.R.; Yin, Y.; Sivakumar, V.; Kang, N.; Yu, X.; Diao, Y.; Adesina, J.; Reddy, R. Aerosol climatology and discrimination of aerosol types retrieved from MODIS, MISR and OMI over Durban (29.88 ${ }^{\circ}$, $\left.31.02^{\circ} \mathrm{E}\right)$, South Africa. Atmos. Environ. 2015, 117, 9-18. [CrossRef]

64. Bhatia, N.; Tolpekin, V.A.; Stein, A.; Reusen, I. Estimation of AOD Under Uncertainty: An Approach for Hyperspectral Airborne Data. Remote Sens. 2018, 10, 947. [CrossRef]

65. Egan, W.G.; Hilgeman, T.W. Optical Properties of Inhomogeneous Materials: Applications to Geology, Astronomy, Chemistry, and Engineering; Academic Press: San Diego, CA, USA, 1979.

66. Querry, M.R.; Osborne, G.; Lies, K.; Jordon, R.; Coveney, R.M. Complex refractive index of limestone in the visible and infrared. Appl. Opt. 1978, 17, 353-356. [CrossRef] [PubMed]

67. Querry, M.R. Optical Constants; U.S. Army Chemical Research and Development Center (CRDC): Aberdeen, MD, USA, 1985; p. 418. 21001.

68. Malitson, I.H. Interspecimen comparison of the refractive index of fused silica. J. Opt. Soc. Am. 1965, 55, 1205-1209. [CrossRef]

69. Ghosh, G. Dispersion-equation coefficients for the refractive index and birefringence of calcite and quartz crystals. Opt. Commun. 1999, 163, 95-102. [CrossRef]

70. Long, L.; Querry, M.; Bell, R.; Alexander, R. Optical properties of calcite and gypsum in crystalline and powdered form in the infrared and far-infrared. Infrared Phys. 1993, 34, 191-201. [CrossRef] 